NBER WORKING PAPER SERIES

\title{
THE IMPACT OF INCREASED COST-SHARING ON UTILIZATION OF LOW VALUE SERVICES: EVIDENCE FROM THE STATE OF OREGON
}

\author{
Jonathan Gruber \\ Johanna Catherine Maclean \\ Bill J. Wright \\ Eric S. Wilkinson \\ Kevin Volpp \\ Working Paper 22875 \\ http://www.nber.org/papers/w22875 \\ NATIONAL BUREAU OF ECONOMIC RESEARCH \\ 1050 Massachusetts Avenue \\ Cambridge, MA 02138 \\ December 2016
}

Research reported in this publication was supported by grant number 72132 from the Robert Wood Johnson Foundation. The content is solely the responsibility of the author(s) and does not necessarily represent the official views of the sponsor. We would like to thank Joan Kapowich, Haizhen Lin, and session participants at the 2015 Academy Health Annual Research Meeting and the 2016 American Society of Health Economists Biennial Meeting for helpful comments. We are grateful to Christopher Behrer, Andrew Goodman, Lynn Hanson, Lori Moye, and Leif Rustvold for outstanding data assistance. All errors are our own. The views expressed herein are those of the authors and do not necessarily reflect the views of the National Bureau of Economic Research.

At least one co-author has disclosed a financial relationship of potential relevance for this research. Further information is available online at http://www.nber.org/papers/w22875.ack

NBER working papers are circulated for discussion and comment purposes. They have not been peer-reviewed or been subject to the review by the NBER Board of Directors that accompanies official NBER publications.

(C) 2016 by Jonathan Gruber, Johanna Catherine Maclean, Bill J. Wright, Eric S. Wilkinson, and Kevin Volpp. All rights reserved. Short sections of text, not to exceed two paragraphs, may be quoted without explicit permission provided that full credit, including (C) notice, is given to the source. 
The Impact of Increased Cost-sharing on Utilization of Low Value Services: Evidence from the State of Oregon Jonathan Gruber, Johanna Catherine Maclean, Bill J. Wright, Eric S. Wilkinson, and Kevin Volpp

NBER Working Paper No. 22875

December 2016

JEL No. I1,I11,I13

\section{ABSTRACT}

In this study we examine the impact of a value-based insurance design (V-BID) program implemented between 2010 and 2013 at a large public employer in the state of Oregon. The program substantially increased cost-sharing, specifically copayments and coinsurance, for several healthcare services believed to be of low value and overused (sleep studies, endoscopies, advanced imaging, and surgeries). Using a differences-in-differences design coupled with granular, administrative health insurance claims data, we estimate the change in low value healthcare service utilization among beneficiaries before and after program implementation relative to a comparison group of beneficiaries who were not exposed to the V-BID. Our findings suggest that the V-BID significantly reduced utilization of targeted services. These findings have important implications for both public and private healthcare policies as V-BID principles are rapidly proliferating in healthcare markets.

Jonathan Gruber

Department of Economics, E52-434

MIT

77 Massachusetts Avenue

Cambridge, MA 02139

and NBER

gruberj@mit.edu

Johanna Catherine Maclean

Department of Economics

Temple University

Ritter Annex 869

Philadelphia, PA 19122

and NBER

catherine.maclean@temple.edu

Bill J. Wright

Center for Outcomes Research and Education

Providence Health \& Services

bill.wright@providence.org
Eric S. Wilkinson

Temple University

1301 Cecil B. Moore Avenue

Ritter Annex 847

Philadelphia, PA 19122

eric.wilkinson@temple.edu

Kevin Volpp

University of Pennsylvania

120 Blockley Hall

423 Guardian Drive

Philadelphia, PA 19104

volpp70@wharton.upenn.edu 


\section{Introduction}

Healthcare expenditures in the United States are high: in 2014 the U.S. spent \$3 trillion dollars on healthcare, this figure represents $17.5 \%$ of the nation's gross domestic product (GDP) (National Center for Health Statistics 2016). This high spending does not appear to have translated into improved health outcomes for Americans. For example, although the U.S. has the highest per capita healthcare expenditures of any Organization for Economic Co-operation and Development (OECD) country, the U.S. also has the highest obesity rate among these countries and ranks $28^{\text {th }}$ out of the 34 OECD member nations in terms of life expectancy (Organization for Economic Co-operation and Development 2014).

These statistics suggest that value in terms of health given expenditures on healthcare services in the U.S. is not optimal: expenditures are high while outcomes are poor. Indeed, in 2012 the Academy of Medicine estimated that 30\% of annual healthcare expenditures, totaling roughly $\$ 750$ billion, were wasteful (Smith, Saunders et al. 2013). Moreover, one half of these wasteful expenditures were attributable to low value services and inefficient healthcare use (Smith, Saunders et al. 2013).

In response to the expenditure of large amounts of resources on services that provide little value in improving health, policy-makers, payers, providers, and employers have displayed great interest in developing strategies to contain healthcare costs. Many of these strategies involve increasing cost-sharing for patients. The expectation, based on basic demand theory, is that increasing out-of-pocket costs to patients will reduce utilization and, in turn, costs. A concern with such a strategy, however, is that increasing across-the-board patient cost-sharing may reduce use of both high and low value care since consumers will often have difficulty differentiating between the two. Recent work on high deductible health insurance plans supports 
this hypothesis (Beeuwkes, Haviland et al. 2011, Brot-Goldberg, Chandra et al. 2015, Huckfeldt, Haviland et al. 2015, Haviland, Eisenberg et al. 2016). Importantly, such short-run reductions in prevention services may increase downstream costs as diseases remain undiagnosed for longer periods and chronic conditions worsen without appropriate treatment (Fendrick, Smith et al. 2001, Hsu, Price et al. 2006b, Heisler, Choi et al. 2010, Campbell, Allen-Ramey et al. 2011). In recognition of the need for a nuanced strategy, the concept of value-based insurance designs (V-BID) emerged in the late 1990s (Fendrick, Smith et al. 2001). V-BID designs are based on basic economic principles: use out-of-pocket prices (the prices most visible to patients) to steer patients away from unnecessary or wasteful healthcare and toward beneficial and necessary healthcare. In the jargon of V-BID, unnecessary or wasteful care is referred to as 'low value' and beneficial or necessary care is referred to as 'high value'. In practice, a V-BID program will typically increase patient cost-sharing for low value care, decrease cost-sharing for high value care, or some combination of these two approaches, although programs have generally focused on decreasing cost-sharing for high value care (Volpp, Loewenstein et al. 2012). The programs may be applied to all patients or specific patient types.

Due to its conceptual appeal, V-BID principles have gained traction among policy makers, employers, and providers. Indeed, this concept has been incorporated into the framework of the Affordable Care Act (ACA) through, for example, co-payment waivers for all preventive services that receive and 'A' or 'B' rating by the U.S. Preventive Services Task Force. ${ }^{1}$ Medicare Advantage has explicitly adopted V-BID into its Health Plan Innovations Initiative. ${ }^{2}$ U.S. states have also implemented such principles into employee benefit plans

\footnotetext{
${ }^{1}$ The full list of services can be located at: http://www.uspreventiveservicestaskforce.org/Page/Name/uspstf-a-andb-recommendations/ (accessed September $9^{\text {th }}$, 2016).

${ }^{2}$ The program focuses on reduced cost-sharing for high value services: https://innovation.cms.gov/initiatives/VBID (accessed September $6^{\text {th }}$, 2016).
} 
(Gibson, Maclean et al. 2015, Hirth, Cliff et al. 2016). A recent survey of large firms documented that $81 \%$ either currently incorporate V-BID principles in their benefit packages or plan to introduce these principles in the near future (Gibson, Maclean et al. 2015).

Beginning in 2011 the American Board of Internal Medicine Foundation launched the 'Choosing Wisely' initiative. ${ }^{3}$ The objective of this initiative is for each participating physician society to identify five specialty-specific low value services and to encourage their physicians to avoid these services. For example, the American Academy of Family Physicians recommends against routine screens for prostate cancer using a prostate-specific antigen (PSA) test. Over 60 professional societies have developed such a list, leading to over 300 services listed as low value (Gawande, Colla et al. 2014). Thus, V-BID principles are likely to become increasingly prevalent in both benefit designs and clinical practice in the near future.

Unfortunately, despite its conceptual appeal, the empirical basis for many V-BID strategies is not strong. A number of studies, reviewed below, show that reduced cost-sharing for high-value services can increase use of these services, but the response has been modest at best. At the same time, there is much less evidence on the degree to which raising the cost of low-value services lowers use of these services - despite the conceptual work of Volpp, Loewenstein et al. (2012) suggesting that increasing cost-sharing for low value care may be more effective than previous efforts of rewarding the use of high value care.

The contribution of this paper is to provide the first careful empirical evaluation of higher cost-sharing for a range of low value services. In particular, we study the impact of an innovative V-BID program implemented by a large public employer in the state of Oregon on utilization of services deemed by plan administrators to be low value and/or overused by patients (Kapowich 2010). This program substantially increased patient cost-sharing for sleep studies,

\footnotetext{
${ }^{3}$ http://www.choosingwisely.org/; accessed May 16 ${ }^{\text {th }}, 2016$.
} 
upper gastrointestinal endoscopies, advanced imaging services, and potentially overused surgery services (e.g., spinal surgery for pain). For example, co-payments for these services increased by $\$ 100$ to $\$ 500$, which in percentage terms is $46 \%$ to $159 \%$.

We use a differences-in-differences design to compare changes in outcomes before and after V-BID program implementation between beneficiaries at the participating employer and beneficiaries receiving health insurance through a comparison group of employers. The V-BID program increased patient cost-sharing (specifically, copayments and coinsurance) beginning in 2010. We leverage granular, administrative claims data between 2008 and 2013 to examine program effects, allowing us to track effects for three years post-implementation.

Our findings suggest that the V-BID program significantly reduced use of targeted low value services. Overall, we find that use of the targeted services fell by $11.9 \%$ on the extensive margin due to the program, with an implied price elasticity of -0.12 which suggests that demand for these services is highly inelastic. There is some variation across services, with reductions of more than $20 \%$ for sleep studies and low-value surgeries, by $7.7 \%$ for advanced imaging services, and by $12 \%$ for endoscopies. These results illustrate for the first time that significant increases in cost sharing on low-value services can greatly reduce their use.

This manuscript is organized as follows: Section 2 briefly describes the literature on VBID effects. The V-BID program examined in this study is outlined in Section 3. Data, variables, and methods are outlined in Section 4. In Section 5 we present our main findings, and Section 6 reports robustness checks and extensions to the main analyses. Section 7 offers a discussion of the findings, limitations, and policy implications.

\section{Previous research on V-BID programs and low-value healthcare services}


In this section we briefly review the V-BID literature, and provide a discussion of efforts to classify healthcare as low and high value. For more detailed discussions of this literature, we refer readers to excellent reviews by Gibson, Maclean et al. (2015) and Look (2015).

\subsection{Previous research on V-BID programs}

A large and growing body of research seeks to estimate the impact of V-BID programs on healthcare utilization, overall utilization, and patient outcomes. The majority of studies have examined V-BID programs that reduce cost-sharing for high value services, and in particular prescription medications. The literature focusing on reduced cost-sharing for high value medications has shown some evidence that reduced cost-sharing leads to improvement in adherence (Maciejewski, Farley et al. 2010, Farley, Wansink et al. 2012, Maciejewski, Wansink et al. 2014, Look 2015). However, the estimated effect sizes are often small. For example, when Aetna members were randomized to free cardiovascular medication for the year following a heart attack average adherence increased from 39\% to 45\%, or 15\% (Choudhry, Avorn et al. 2011). Given the serious nature of this health shock and the complete removal of copayments, this effect size is quite modest. In addition, a recent review of the literature suggests that V-BID programs can improve medication adherence, on average, by 3 percentage points per year (Lee, Maciejewski et al. 2013).

Several studies that examine V-BID programs targeting high value services with reduced cost-sharing suggest that while such programs improve adherence and increase medication/service use, they may not lead to substantial - or any - reductions in costs (Lee, Maciejewski et al. 2013, Maciejewski, Wansink et al. 2014, Hirth, Cliff et al. 2016, Sepúlveda, Roebuck et al. 2016). These studies imply that V-BID programs that reduce cost-sharing for high value services may not generate the savings that program designers might hope would be 
achieved through better health and thereby lower rates of adverse events triggering emergency room visits or hospitalizations.

As noted by Volpp, Loewenstein et al. (2012), reductions in copayments for high value care potentially have modest effects due to the asymmetry of losses and gains (people are more adversely affected by a loss than an equivalent dollar gain) and the proverbial 'dog that didn't bark' problem in which copayment reductions may be less visible to non-adherent plan members (the target of programs that reduce cost sharing) compared to the impact of a copayment increase (which largely affects already adherent plan members). In other words, rewarding adherent patients with reduced cost-sharing likely has less effect than penalizing non-adherent patients or patients using lower value care with increased cost-sharing. This argument is laid out conceptually by Volpp, Loewenstein et al. (2012), who state that increasing cost-sharing for low value care may be more effective than previous efforts of encouraging the use of high value care through lower cost sharing.

A handful of studies has examined the impact of increasing cost-sharing for low value healthcare services, specifically emergency department (ED) usage (Nair, Miller et al. 2010, Choudhry, Fischer et al. 2012, Siddiqui, Roberts et al. 2015). For example, Siddiqui, Roberts et al. (2015) take advantage of state-level changes in Medicaid cost-sharing for ED usage induced by the 2008 to 2010 recession. Specifically, the Deficit Reduction Act of 2005 gave states the authority to impose cost-sharing strategies on healthcare services. During the 2008 to 2010 recession, eight states adopted cost-sharing for non-urgent ED. Using a differences-indifferences design, the authors find no evidence that increases in cost-sharing impacted ED utilization within the Medicaid population. However, Hsu, Price et al. (2006a) and Hirth, Cliff et al. (2016) find that increases in cost-sharing do reduce ED usage, although the effects on overall 
healthcare costs are inconclusive. Thus, the ability of V-BID programs to reduce low value healthcare service utilization and costs may be context-specific. ${ }^{4}$

A necessary condition for V-BID programs to affect utilization and costs is employee awareness of the program (Baicker and Levy 2015). However, the available evidence suggests that, in many cases, employees have incomplete knowledge of program existence and the specific services targeted (Henrikson, Anderson et al. 2014). Thus, lack of knowledge may have hindered previous efforts to effectively utilize V-BID principles in benefit designs.

In a recent review of the V-BID literature investigating medication adherence and costsharing, Look (2015) documents that many studies suffer from methodical issues. For example, numerous studies lack a comparison group and instead rely on before-after designs to estimate effects. Look notes that these study limitations impede our ability to understand V-BID effectiveness and encourages the use of more credible research designs within the literature.

In summary, the V-BID literature suggests that reducing cost-sharing for high value medications may increase adherence although the impacts on patient outcomes, overall utilization, and costs is less clear. Moreover, the literature that studies the impact of increasing cost-sharing for low value services is nascent and few studies have considered healthcare services beyond ED usage. Overall, much of the exiting V-BID literature is subject to numerous methodological flaws. In this study, we aim to address some of these research gaps by using a credible research design (differences-in-differences) to study the effect of increasing patient costsharing for a set of general healthcare services that are believed to be overused by patients.

\subsection{Classification of low value care}

\footnotetext{
${ }^{4}$ Although beyond the scope of this study, there is a substantial economic literature that investigates the impact of cost-sharing on utilization more broadly than within the context of V-BID programs (Baicker and Goldman 2011).
} 
Although critical to the study of any V-BID program, there is, to the best of our knowledge, no official definition of low value care and different studies apply different definitions (Garner, Docherty et al. 2013). However, most definitions are broadly consistent with the notion that low value care is care for which there is a lower cost and equally effective form of care. Thus, the concept of low value care can be applied to a broad set of healthcare services. Moreover, it be may involve no treatment ('watchful waiting') in some cases.

Although there is general agreement on low value care in concept and the need to reduce it, there is much less agreement in identifying what care is in fact low value (Rosenbaum 2013, Gawande, Colla et al. 2014). Moreover, a particular service may be low value for some patients, but not for others. Thus, even if we were able to identify a set of services that were, on average, low value there are likely numerous patients for whom these services would be of higher clinical value. As the literature is still nascent in this area, V-BID studies - including our own examining low or high value care are vulnerable to the critique that the programs they study are targeting care that is valuable, or not valuable, for some patients. Our study will not address this important issue, but we note that more research efforts are critically needed to identify the value of specific services and for which patient types.

\section{The current V-BID program}

\subsection{Program details}

We examine the impact of a V-BID program implemented at a large public employer in the state of Oregon: the Oregon Educators Benefit Board (OEBB). ${ }^{5}$ OEBB provides benefits for approximately 150,000 current or retired employees of school districts, education service districts, and community colleges in Oregon and their dependents. These benefits are provided through two contracted health plans_-Kaiser Permanente, which offers HMO plans, and Moda

\footnotetext{
${ }^{5}$ http://www.oregon.gov/oha/OEBB/Pages/index.aspx; Accessed May 17 $7^{\text {th }}$, 2016,
} 
Health, which provides PPO plans. Prior to October $1^{\text {st }}, 2012$ OEBB also offered PPO plans through Providence Health Plan. OEBB offers different plan designs to the school districts, education service districts, and community colleges/charter schools it serves. We are unable to obtain data on the universe of OEBB plans. Specifically, we have data on all Moda Health plans, but we do not have access to Kaiser Permanente or Providence Health plans. Moda Health plans cover $75 \%$ of the beneficiary population. Appendix Table A reports the share of the OEBB population captured in our data in each year of our study period. Although we cannot study Kaiser Permanente and Providence Health plans, the OEBB V-BID impacted all plans held by OEBB beneficiaries (thus, impacted plans managed by all three issuers) ${ }^{6}$ Hence, we have no reason ex ante to suspect that beneficiaries switched to a non-Moda Health insurance plan in response to the V-BID (e.g., to avoid exposure to increases in cost-sharing).

OEBB plan years run October $1^{\text {st }}$ to September $30^{\text {th }}$. Over our study period, a total of 15 different PPO plans were offered to OEBB beneficiaries. Beginning October $1^{\text {st }}, 2012$, Moda Health re-organized its plan offerings. More specifically, several plans were eliminated and new places were developed to better meet the beneficiary needs. This change has some implications for our study. In particular, one may be concerned that re-organization of the plans may impact our ability to estimate causal effects as the re-organization may have induced beneficiaries to select a new plan. Indeed those holding terminated plans were forced to switch plans, which could offer lower cost-sharing. However, this plan changed occurred two years after the V-BID program was implemented, thus we suspect that any induced switching in plan holding due to the

\footnotetext{
${ }^{6}$ However, we note that Kaiser Permanente plans were later in adopt cost-sharing increases and for a smaller set of services (i.e., advanced imaging services). Our conversations with Kaiser Permanente administrators revealed that this system relies on provider-side gatekeeping to contain healthcare costs. Thus, administrators do not believe that they require to implement additional demand-side cost-containment strategies.
} 
plan re-organization is small. We more formally address this potential threat to our research design later in the manuscript.

OEBB implemented its V-BID program on October $1^{\text {st }}$, 2010. The V-BID program targeted both pharmaceutical medications (Value Based Pharmacy or 'VBP' ${ }^{7}$ ) and healthcare services (Additional Cost Tier or 'ACT'). We focus our attention on the ACT in this study; we will discuss the potential role of the VBP below.

Administrators at OEBB relied on information from the Dartmouth Atlas of Health Care ${ }^{8}$ and Oregon Health Evidence Review Commission ${ }^{9}$ to classify services as low value. In addition to these sources, OEBB administrators also utilized information from internal analysis of OEBB healthcare claims data to classify such services. Kapowich (2010) provides a detailed discussion of the development of the list of targeted services.

Table 1 outlines the affected services, the date of the cost-sharing increase, and the level of the cost-sharing increase. The affected services include: sleep studies (home studies and studies conducted in a healthcare facility); upper gastrointestinal endoscopies; advanced imaging services including computerized tomography (CT) scan, magnetic resonance imaging (MRI), and

\footnotetext{
${ }^{7}$ The VBP focused on four classes of drugs: generic, value, preferred, and non-preferred. Cost-sharing (copayments) for generic drugs was eliminated and reduced for value and preferred drugs while cost-sharing for non-preferred drugs increased. The Moda Health benefit plan books state that value drugs include select commonly prescribed products used to treat clinical medical conditions and preserve health. Examples of value drugs are Atenolol which is a beta blocker and Lovastatin which is a statin. Generic drugs on the VBP are determined by doctors and pharmacists to be therapeutically equivalent to the brand name version. This drug tier may also include some branded drugs that have been identifiable from a clinical and cost-effective perspective. Generic drugs on the VBP include Albuterol which opens up airways in the lungs and Clonidine which is used to treat, among other things, high blood pressure, ADHD, anxiety, and substance use withdrawal symptoms. Preferred drugs include medications which have limited alternatives available but have been found to be clinically effective and at a favorable cost relative to non-preferred alternatives, and include select generic drugs that have been identified as having no more favorable outcomes from a clinical perspective than more cost effective generic drugs. Medications included in the preferred tier include Abilify which is used to treat schizophrenia and bipolar disorder, and Zomig which treats migraine headaches. Finally, non-preferred drugs have been reviewed by plan administrators and are found to have no significant treatment or cost advantage over preferred tier drugs. Non-preferred drugs include Patanol which is used to treat allergic conjunctivitis and Zovirax which is used to treat herpes.

${ }^{8}$ http://www.dartmouthatlas.org/; accessed May 14 ${ }^{\text {th }}, 2016$.

${ }^{9}$ http://www.oregon.gov/oha/herc/Pages/index.aspx; accessed May 14 $4^{\text {th }}, 2016$.
} 
positron tomography (PET) scans; and potentially overused surgeries including spine surgeries for pain, knee and shoulder arthoscopies, and hip and knee replacements (we refer to the potentially overused surgeries as simply ‘surgeries’ henceforth).

Not all of these services are universally low value; for example, home sleep studies typically are much higher value than facility-based sleep studies, which offer similar testing often at more than ten times the price. Upper gastrointestinal endoscopies can be life-saving when preformed for gastrointestinal bleeding while advanced imaging can be necessary for diagnosis, and spinal surgery can also be clinically indicated. However, many of these procedures may be over-utilized and in any given proportion the ratio of these services that are high vs. low value is likely quite low. Since we cannot judge appropriateness of the service use in our data we simply evaluate here the impact of increased cost sharing on service utilization.

We note that healthcare providers are permitted some degree of discretion in the application of the increased cost-sharing, and that the V-BID program was developed to exclude emergency (e.g., trauma) healthcare use and care related to life-threatening health conditions (e.g., cancer) from the increased cost-sharing. Therefore, it seems reasonable to assume that when an ACT service would be of high value for a patient (e.g., an upper gastrointestinal endoscopy when a patient is experiencing gastrointestinal bleeding) a provider may apply such discretion or the service classification system would reflect the potential value of the service to a patient facing a life-threatening health condition. ${ }^{10}$

ACT copayments and coinsurance must be paid in addition to a beneficiary's plan deductible, regular copayment, or coinsurance. Moreover, the increased cost-sharing does not accrue to the plan out-of-pocket maximum. OEBB administrators intended the increased cost-

\footnotetext{
${ }^{10}$ Our conversations with OEBB health plan administrators are consistent with this hypothesis. More details are available from the corresponding author.
} 
sharing to act as an incentive for beneficiaries to learn about potential cost-effective alternatives and discuss these alternatives with their providers.

Before the implementation of the ACT, there were no copayments for these services, and there were coinsurance rates ranging from 10\% (sleep studies and advanced imaging) to 30\% (endoscopy and surgery). Copayments were increased for all services we study on October $1^{\text {st }}$, 2010. ${ }^{11}$ The copayment increases are as follows: \$100 for sleep studies, \$500 for endoscopies (copayments for this service were reduced to $\$ 100$ on October $1^{\text {st }} 2011$; OEBB administrators state that the reduction was implemented to better align costs with beneficiary needs), $\$ 100$ for advanced imaging services, and \$500 for surgeries considered here. Coinsurance was increased by 10 percentage points on October $1^{\text {st }} 2010$ for endoscopy and surgery (taking each to $40 \%$ coinsurance), and by 10 percentage points on October $1^{\text {st }} 2011$ for sleep studies and advanced imaging (taking each to 20\% coinsurance). ${ }^{12}$ Thus, these changes in cost-sharing arguably represent a substantial increase in the out-of-pocket payments faced by beneficiaries.

As noted earlier in the manuscript, a concern with analysis of any V-BID program is the extent to which beneficiaries are aware of the program. If beneficiaries are not aware of the program, it is unlikely that the program will lead to substantial changes in utilization. Kapowich (2010) provides a detailed review of the extensive efforts OEBB administrators applied to ensure good knowledge of the V-BID program among beneficiaries.

To support effective messaging of the program to beneficiaries, OEBB administrators contracted with a media consulting firm to craft a communication plan. Prior to the October $1^{\text {st }}$,

\footnotetext{
${ }^{11}$ OEBB also changed cost-sharing for several other services. For example, cost-sharing was increased for bariatric surgery on October $1^{\text {st }} 2012$. However, these services are very infrequently used by OEBB beneficiaries. We attempted to explore the impact of the V-BID on utilization of these services, but small sample sizes prevented us from examining these outcomes with confidence. Details are available on request from the corresponding author. ${ }^{12}$ In our analysis of the OEBB data, we do see some non-zero copayments in the data in the pre-treatment period. However, these copayments are small in magnitude and we suspect that they are an artifact of data entry errors rather than true cost-sharing for these services. More details are available from the corresponding author.
} 
2010 launch date, administrators provided information through the OEBB website, e-mail, pamphlets, and in-person meetings in their efforts to inform beneficiaries. Indeed, our conversations with OEBB administrators suggest that beneficiaries were well aware of the program. For example, OEBB administrators indicated that their benefits office received an increase in emails and telephone calls from beneficiaries in reference to the V-BID program, further suggesting that the beneficiaries were aware of the V-BID. However, we note that we lack an objective measure of the effectiveness of these communication efforts and it is possible that communication regarding the V-BID to beneficiaries was sub-optimal.

One concern with our analysis is that we may not be able to isolate the effect of the ACT on outcomes from any VBP that went in at the same time. However, we suspect that because the ACT and VBP targeted different services (overused and lower value procedures vs. both high and low value medications), any cross-program spillover effects are likely small. Our review of the medications targeted by the VBP suggests that they are not obviously directly linked with most of the healthcare outcomes we study here. For example, we study a set of general healthcare procedures (i.e., sleep studies, endoscopies, advanced imaging services, and potentially overused surgeries) for which most medications targeted by the VBP do not appear to be a direct complement. Indeed, our review of the medications suggests that very few of the targeted medications would be used directly in conjunction with the procedures we study here. In unreported analyses, we explored the impact of the VBP on use of targeted medications and found no evidence that the program reduced utilization of targeted medications. ${ }^{13}$

\footnotetext{
${ }^{13}$ Indeed, our regression coefficient estimates were 'wrong-signed' or imprecise. We suspect that the complexity of the VBP program may have confused some patients, leading to the difficult to understand results. Overall, we interpret our analysis of the VBP program to suggest that this program did not have the expected impact on medication use (i.e., reduce use of low value medications and increase use of high value medications). Thus, we do not suspect substantial spillovers from the VBP to the ACT program we study here.
} 
However, we do note that for some services we study some of the VBP medications may be substitutes (e.g., pain management medications such as Fentanyl may substitute for spinal surgeries to address pain). Thus, we acknowledge that we cannot definitively rule out the possibility of spillover effects from the VBP program to the services we study as the ACT and VBP programs were implemented simultaneously. Indeed, one way to interpret our results is as the combined impact of the ACT which increased cost-sharing for low value general healthcare services and the VBP which applied increases and decreases in cost-sharing for high and low value medications. Our hypothesis is that the vast majority of any treatment effects we estimate in our study are attributable to the ACT and not the VBP. We formulate this hypothesis based on the fact that direct and substantial adjustments in cost-sharing for the targeted procedures is likely to have a far greater effect on service utilization for these conditions than indirect effects through modifying cost-sharing for medications.

\section{Data and methods}

\subsection{Comparison group}

In this study, our objective is to estimate the causal effect of the OEBB V-BID program on healthcare utilization using differences-in-differences (DD) models. Thus, we require a valid comparison group for OEBB. To this end, we obtained comparable health insurance claims data on three additional public employers in the state of Oregon that did not implement V-BID programs before or during our study period (2008 to 2013): Portland General Electric (PGE) employees, Washington County employees, and Clackamas County employees. ${ }^{14}$

PGE is an electrical utility company based in Portland that employed 2,603 employees in 2011. Washington County and Clackamas County are the second and third largest counties in the state of Oregon with 529,000 and 376,000 residents respectively in 2010. PGE and both

\footnotetext{
${ }^{14}$ We received these data from Providence Health.
} 
counties are located in the northwest corner of Oregon. The three employers in our comparison group offer one contracted point of service plan to beneficiaries through Providence Health, and these plans did not change throughout our study period. Plan years at the comparison companies run January $1^{\text {st }}$ to December $31^{\text {st }} \cdot 15$

A critical assumption for the DD model to uncover causal effects is that OEBB and the comparison group (PGE, Washington County, and Clackamas County) would have trended similarly in terms of the outcome variables had OEBB not implemented the V-BID program. This assumption is inherently untestable, but we provide suggestive evidence on this assumption later in the manuscript by testing parallel trends in outcome variables in the pre-treatment period.

\subsection{Data}

To study the impact of the OEBB V-BID program, we use granular, line-by-line healthcare claims data on all four companies; we obtained these data through data use agreements with Moda Health (OEBB data) and Providence Health (PGE, Washington County, and Clackamas County data). These data include all healthcare encounters for which Moda Health and Providence Health insurance plans were used for payment of OEBB, PGE, Washington County, and Clackamas County beneficiaries over this time period.

We make several exclusions to the claims data to form our analysis sample. First, we exclude all beneficiaries under age 19 and over age 64; we exclude such beneficiaries as they potentially have access to public health insurance (e.g., Medicaid, Medicare) and therefore may be somewhat insulated from the V-BID attributable increases in cost-sharing.

Second, we retain only beneficiaries who are continuously enrolled for the duration of our study period (we report later in the manuscript that our results are robust to loosening this

\footnotetext{
${ }^{15}$ Although the comparison company plan years run January to December, we use data on comparison companies to match the OEBB plan years (October to September).
} 
restriction). Thus, we have a balanced panel of beneficiaries. We chose to exclude noncontinuously enrolled beneficiaries to minimize concerns regarding compositional change within the analysis sample. It is possible that continuously enrolled beneficiaries capture a select subset of all OEBB and comparison company beneficiaries.

Appendix Table B reports demographics for the continuously enrolled sample and noncontinuously enrolled sample (we exclude beneficiaries who are not enrolled for 12 months in each plan year to form this latter group as we wish to consider only those beneficiaries likely to be meaningfully exposed to the V-BID program). Although there are statistically significant differences across these two groups, in general the differences are practically small. Thus, we interpret this analysis to imply that focusing on the continuously enrolled sample does not lead to substantial sample selection. However, we return to this issue later in the manuscript.

These exclusions leave us with 2,391,780 beneficiary/year observations in our analysis sample, 2,159,520 at OEBB; 53,340 at PGE; 91,359 at Washington County; and 87,561 at Clackamas County. In all analyses, we collapse the data to the beneficiary-month-year level. Thus, observations capture per beneficiary per month cost-sharing and service utilization. Our study period includes 60 months of data, 24 months pre-V-BID and 36 months post-V-BID.

We obtained the specific procedure and diagnosis codes (CPT, HCPCS, and ICD-9) used by OEBB billers to determine if a particular service was subject to increased cost-sharing. ${ }^{16} \mathrm{~A}$ limitation of our analysis is that the OEBB codes change across plan year. Administrators at OEBB report that these changes were made to better meet the needs of beneficiaries and to more accurately reflect low value services relevant to the beneficiary population. Certain health conditions (e.g., cancer, trauma) exempt beneficiaries from the ACT increased cost-sharing; we incorporate these exemptions into the coding of our outcome variables (described later in the

\footnotetext{
${ }^{16}$ Details on specific codes are available from the corresponding author.
} 
manuscript). ${ }^{17}$ In our main analyses we examine services that were ever listed as an ACT service, but in a robustness check reported later we examine services that were listed as an ACT service in all years of the program. Our results are not sensitive to this change in coding.

\subsection{Outcome variables}

To test whether the V-BID cost-sharing increases were in fact passed through to beneficiaries, we measure the sum of copayments and coinsurance for each service targeted by the program: sleep studies, endoscopies, advanced imaging services, and surgeries.

To examine the impact of the V-BID on health care utilization, we create several measures. The first is an indicator for whether the beneficiary utilized each of the targeted services. The second is a count of the number of episodes of care that involve a targeted service. ${ }^{18}$ We also construct comparable payment, any utilization, and service count for overall ACT service use (that is use of any of the ACT services).

\subsection{Control variables}

We include demographic information available in our claims data in regression models. Specifically, we include age in years, sex (male, with female as the omitted category), and dependent status (spouse and child, with employee as the omitted category).

\subsection{Empirical model}

We estimate the impact of our V-BID programs on cost-sharing and utilization with the following differences-in-differences regression model:

$$
Y_{i e t}=\alpha_{0}+\alpha_{1} D D_{e t}+\alpha_{2}^{\prime} X_{i e t}+E_{e}+m_{m}+\tau_{t}+\varepsilon_{i e t}
$$

$Y_{\text {iet }}$ is an outcome measure for beneficiary $i$ at employer $e$ in period $t . D D_{e t}$ is the differences-in-differences estimate, it is the interaction between the treatment group (OEBB) and

\footnotetext{
${ }^{17}$ More specifically, if diagnoses codes indicate that a patient suffers from a health condition that would exempt him from the ACT cost-sharing, we do not code that service as an ACT service.

${ }^{18}$ We define a care episode as a set of services that have the same member ID, start date, and billing provider.
} 
the post period (October $1^{\text {st }}, 2010$ and onward). ${ }^{19} X_{\text {iet }}$ is a vector of beneficiary characteristics. $E_{e}$ is a vector of employer fixed effects, $m_{m}$ is a vector of month-of-year fixed effects to capture any seasonality in healthcare use, and $\tau_{t}$ is a vector of period fixed effects. We do not include plan fixed effects in our core regression model as Moda Health implemented a major reorganization of its plans during our study period. However, in sensitivity checking we show that our results are robust to including plan fixed effects. Inclusion of month fixed effects allows us to control for any seasonality in healthcare outcomes. Period fixed effects control for trends in outcomes that are experienced by all employers. Lastly, $\varepsilon_{i e t}$ is the error term.

We calculate robust standard errors in our main analyses. However, such standard errors may overstate the precision of our estimates as we have just two clusters. In unreported analyses, we calculate estimates of precision using the wild cluster bootstrap which is more suitable when the number of clusters is small (Cameron and Miller 2015). Results are comparable to those reported in the manuscript and are available on request. We use OLS regression when the outcome is continuous. We use linear probability models (LPM) to estimate regressions in which the outcome variable is binary, although findings are not appreciably changed if we instead use a probit model (Ai and Norton 2003, Norton, Wang et al. 2004).

\section{Results}

\subsection{Summary statistics}

Table 2 reports summary statistics in the pre-treatment period for OEBB and the comparison group of companies. The average out-of-pocket (OOP) payments impacted by the V-BID faced by patients at OEBB (comparison companies), i.e., the sum of copayments and coinsurance, are: \$285 (\$104) for sleep studies, \$160 (\$98) for endoscopies, \$195 (\$65) for

\footnotetext{
${ }^{19}$ Employer and year/month fixed effects subsume the treatment and post indicator in a simple DD model.
} 
advanced imaging services, \$339 (\$203) for surgeries, and \$211 (\$88) for any ACT. Thus, in the pre-treatment period, cost-sharing is higher at OEBB than at the comparison companies. Unreported analyses shows that copayments at OEBB were generally zero and the OEBB OOP payments predominately reflect coinsurance.

The services we study are not commonly provided: only $1.7 \%(2.0 \%)$ of the OEBB (comparison companies) sample report using any of these services in the pre-treatment period. ${ }^{20}$ The most frequently provided service is advanced imaging (1.2\% in the OEBB sample and 1.5\% in the comparison group sample), and the least common services are sleep studies $(0.1 \%$ in both the OEBB and comparison group samples) and endoscopies $(0.1 \%$ in the OEBB sample and $0.2 \%$ in the comparison group sample). In general, the share of beneficiaries using these services is higher at the comparison companies than at OEBB in the pre-treatment period while the pattern of results is more mixed in terms of service episodes. Differences across groups are generally statistically distinguishable from zero given our large sample sizes.

The demographics of our sample are broadly comparable to an employed, prime working age population. On average OEBB beneficiaries are older than comparison company beneficiaries (46 years vs. 45 years) and are more likely to be female (58\% vs. 53\%). There are also differences across the distribution of employees, spouses, and children between the groups.

\subsection{Validity of the research design}

Our research design is DD. A critical assumption of this model is that the treatment and comparison groups would have trended similarly in terms of the outcome variables in the post-

\footnotetext{
${ }^{20}$ Recall that our unit of observation is the beneficiary-month-year. Thus, these numbers reflect monthly service use. To estimate annual service use, interested readers can multiply the numbers presented here by 12 . An estimate of the annual ACT propensity to use an ACT service is therefore 20.4\% among OEBB beneficiaries and 24\% among comparison group beneficiaries.
} 
treatment period, had the treatment group not been treated. To explore whether our data support this assumption, we illustrate the pattern in both cost sharing and utilization.

More specifically, Figures 1 to 3 present graphical analyses of unadjusted trends in the outcome variables in the treatment and comparison groups for our study period (October 2010 to September 2013), for any ACT service, both the indicator for any use and the count of the number of episodes (results for specific ACT services are available on request). We include a vertical line to indicate the period in which the V-BID was implemented at OEBB (October 2010). Although our analysis is conducted at the individual-month level, we aggregate these data to the treatment/quarter level to smooth out noise in the estimates.

Figure 1 shows that OOP payments for ACT services (conditional on the use of an ACT service) are on a parallel trend before the policy change, and then jump up for OEBB while remaining flat for the comparison group. This pattern provides reassuring evidence that our policy change was independent of other key cost sharing changes in the comparison sample.

Figures 2 and 3 show that both any use of an ACT service, and the number of episodes of ACT utilization, are also on parallel trends before the policy change, with OEBB utilization above that for the comparison sample. At the time of the policy change, there is a sharp reversal, with OEBB utilization falling before the comparison sample - corresponding to the rise in cost sharing. The timing is once again suggestive of a policy impact as opposed to some pre-existing trend. Given that the unadjusted trends in our outcomes strongly support that the treatment and comparison moved in parallel in the pre-treatment period, we proceed to the main analysis.

\subsection{Effect of the OEBB V-BID on ACT service cost-sharing and service utilization}

Table 3 reports selected regression results from our analysis of the V-BID program on OOP payments (conditional on service use), any utilization, and number of service episodes. In 
terms of cost-sharing (panel A), our results are as expected in terms of sign and are precisely estimated: cost-sharing increases post-V-BID at OEBB relative to comparison companies. More specifically, the cost-sharing increases in OOP payments are as follows (\% increase given in parentheses): \$130 (46\%) for sleep studies, \$245 (153\%) for endoscopies, \$143 (73\%) for advanced imaging services, \$541 (159\%) for surgeries, and \$212 (100\%) for any ACT services (percent changes are calculated by comparing the estimated beta with the mean value in the pretreatment period at OEBB, all tables report the same calculation).

Our decision to condition these OOP payment regressions on use of ACT services has potential implications for interpreting our estimated regression coefficients. If the V-BID impacted the propensity to use services, and if that changed the nature of the patient cost sharing among users, that can lead to sample selection bias. To explore this possibility, we re-estimate the OOP payment regressions on the unconditional sample. Coefficient estimates, reported in Appendix Table C, are comparable in direction and statistical significance to estimates generated in our conditional samples, although the unconditional results are of course much smaller in magnitude since use of these services is rare. We interpret these unconditional OOP payment results to imply that our decision to select on service use does not lead to substantial bias.

Our estimates of the effect of the OEBB V-BID program on utilization of ACT services are reported in panel B. The results suggest that the V-BID reduces utilization of each of the services studied here, but with some variation in the level of statistical significance. Along the extensive margin (any service use), the reduction in utilization from increased cost-sharing is significant for sleep studies, advanced imaging services, and surgeries but not endoscopies. We find that following implementation of the V-BID, OEBB patients are 0.033 percentage points (24\%) less likely to use sleep studies, 0.017 percentage points (12\%) less likely to have 
endoscopies, 0.092 percentage points (8\%) less likely to use any advanced imaging services, and 0.061 percentage points (24\%) less likely to use any of the potentially overused surgery services relative to beneficiaries in the comparison group. For overall ACT services, the propensity of any use declines by 0.20 percentage points or, $12 \%$. The implied price elasticities across services vary from a low of -0.08 (endoscopies) to a high of -0.52 (sleep studies) and across all ACT services the extensive margin elasticity is -0.12 .

The pattern of results is comparable when we turn to our measures of service episodes that involve ACT services in the third panel of Table 3. Following implementation of the V-BID program, the number of sleep studies, endoscopies, imaging, and surgeries decline by 32\%, 11\%, $6 \%$, and $26 \%$, respectively (the coefficient estimate in the endoscopy regression is again imprecise). The decline in overall episodes of ACT service use is 13\%. The implied elasticities across the various services vary from a low of -0.07 (endoscopy) to a high of -0.70 (sleep studies), and the overall elasticity for ACT episodes is -0.13 .

The similar magnitudes for the use of any services and the total number of services used implies that most of the response that we observe is on the extensive margin; indeed, if we estimate a model of conditional utilization of ACT services, we get a zero coefficient for overall service use. This finding is of course not dispositive because models of conditional utilization are subject to potential selection bias, but it is suggestive

Overall, these findings suggest that the V-BID was effective in reducing use of low value services. The response is largest for sleep studies, but very inelastic for other ACT services. The response appears to arise from the extensive margin, not the amount of services received, which makes sense since patients typically only receive one or two of each of these services. For brevity, we have reported results for the DD estimate only. We report a full set of 
regression coefficients for OOPs in Appendix Table D1, any utilization in Appendix Table D2, and service episodes in Appendix Table D3.

\subsection{Allowing for dynamics in program effects: Event study}

In our core regression model, Equation (1), we implicitly impose that the effects of the OEBB V-BID occurred immediately following program implementation and remain constant in the post-program period. Moreover, we do not account for the fact that there may be some anticipatory behavior on either the part of providers or patients in the pre-V-BID period, or other trends in the outcome variables. Failure to consider these dynamics can lead to inaccurate conclusions (Wolfers 2006). We next relax these assumptions to some extent. Specifically, we estimate a variant of Equation (1) which includes leads and lags around the implementation date. More specifically, we include indicators for two years pre-program, the program implementation year, one year post-program implementation, and two years post-program implementation, with two years pre-program as the omitted category. Results are reported in Table 4.

The findings from this analysis are qualitatively similar to our core findings. Importantly, we find no evidence of anticipatory behavior or differential trends between the treatment and comparison groups in the pre-treatment period: the coefficient estimates on the indicator for 2 years pre-V-BID are statistically indistinguishable from zero in all 15 regressions.

In the cost-sharing regression (panel A), we find evidence that patient cost sharing increases substantially in the implementation year, but that patient's exposure to the full costs of the targeted services may decline over time (coefficient estimates decrease monotonically with each year post-V-BID). While we cannot state definitively why patient price exposure declines, it may be driven by price shopping, plan switching, or changes in service classification. 
Our findings for any utilization of the targeted services (panel B) imply dynamics in program effects. First, for surgeries, we see that the reductions in use do not emerge until 1 year post-V-BID (although the coefficient on the indicator for the implementation year is negative, it is imprecise). Interestingly, our dynamic models show that advanced imaging services effects become statistically indistinguishable from zero two years post-V-BID. As in the basic DD regression, coefficient estimates in the endoscopy regressions are not statistically different from zero although they are negative.

\section{Robustness checks}

We next describe several robustness checks we conduct to assess the sensitivity of our findings to alternative modeling approaches. For brevity, we report cost-sharing and any utilization regressions, regressions for episodes are available on request.

\subsection{Unbalanced panel}

Our analyses so far have relied on the panel of beneficiaries who are continuously enrolled throughout our study period. This sample may be selected and therefore our findings may not be generalizable to the broader beneficiary population. A comparison of demographics of the balanced and unbalanced samples (Appendix Table B) reveals some modest differences in terms of demographics between these two groups.

The results of this exercise are reported in Appendix Table E. The coefficient estimates are similar in sign and statistical significance as in the core regressions, but some of the magnitudes are larger. While continuously enrolled beneficiaries may be a selected group, our focus on this group does not appear to fully explain our V-BID findings.

\subsection{Plan switching}


Thus far in the analysis we have not explicitly accounted for, or explored the extent of, any plan switching. If individuals, in response to the V-BID, decide to switch to a different plan, this compensatory behavior may bias our coefficient estimates. To explore this behavior, we reestimate Equation (1) with plan fixed effects. The results of this are shown in Appendix Table F. The coefficient estimates are not appreciably different from those generated in our basic DD models, although the estimated effects and applied price elasticities are somewhat smaller in magnitude. ${ }^{21}$ One possible explanation for the difference in magnitudes between estimates generated in these regressions and our core models is that some beneficiaries switched plans to avoid the increases in cost-sharing attributable to the ACT.

\subsection{Alternative coding for ACT services}

In the core analysis we examine services that listed as an ACT service in any plan year between 2010 and 2013. We next re-estimate our regression models using only those services that were ever listed as an ACT service in all years of the program (i.e., in each year between 2010 and 2013). Results are reported in Appendix Table G and are not appreciably different than our main findings.

\subsection{Other changes in cost-sharing at OEBB}

Unfortunately, for our study, OEBB implemented other changes in cost-sharing during our study period. In particular, OEBB increased deductibles, out of pocket maximums, office visits, and urgent care visits, and the extent of the changes varied across plans (more details on the specific change by plan are available on request). These changes occur at the same time as

\footnotetext{
${ }^{21}$ As noted earlier in the manuscript, Moda Health implemented a re-organization of their health plans between 2012 and 2013. This effort lead to the termination of some plans and introduction of new plans. Although the plan re-organization of the plans occurred several years after the V-BID implementation, we are concerned that the plan changes may have led to additional plan switching on the part of beneficiaries. Hence, we have re-estimated our regressions that control for plan fixed effects excluding plan year 2012-13 (i.e., October 2012 to September 2013). The results are not different and are available on request.
} 
some of the increases in cost-sharing for low value services: October $1^{\text {st }}, 2010$ or October $1^{\text {st }}$, 2011. A concern with our analysis is that the effects we estimate in our regressions reflect the impact of the above-noted changes in general cost-sharing rather than the increases in costsharing for low value services (i.e., sleep studies, upper GI endoscopies, advanced imaging services, and potentially overused surgeries). To explore this possibility, we leverage differences in the increases in general cost-sharing that occurred across OEBB plans.

More specifically, three plans (named 'ODS Plan 3', 'ODS Plan 4', and 'ODS Plan 5') experienced larger increases in general cost-sharing than the remaining plans (named 'ODS Plan 6', 'ODS Plan 7', and 'ODS Plan 8'). In the first set of plans, the copay was significantly increased for specialist office visits, and the deductible was raised by $50 \%$ to $200 \%$. In the latter set of plans, there was no change for specialist office visits, and deductibles rose only at most by 33\%. To provide suggestive evidence that the effects we estimate in our main regressions are predominantly driven by the increases in cost-sharing for low value services rather than general changes in cost-sharing we estimate separate regressions in which our treatment group includes i) ODS Plans 3 to 5 and ii) ODS Plans 6 to 8. If we find that the effects we estimate in these two sets of regressions are qualitatively similar, then it is a plausible assumption that the increased cost-sharing for low value services drives our findings. ${ }^{22}$

Results from this analysis are reported in Appendix Table H. For brevity, we report only the cost-sharing and any utilization for the any ACT regressions, but regressions for specific services are available on request. The results are comparable across both groups of plans. For example, utilization of any ACT service declined by 13\% in ODS Plans 3 to 5 following implementation of the V-BID relative to the comparison companies while the decline was 10\%

\footnotetext{
${ }^{22}$ As noted in earlier in the manuscript, between 2012 and 2013 Moda Health re-organized its plan offerings. Some of the ODS Plans were dropped and others were altered to some extent and re-named. Due to these changes in the ODS plans, we estimate the separate regressions on the October $1^{\text {st }}, 2008$ to September $30^{\text {th }}$, 2012 period only.
} 
in ODS Plans 6 to 8 . The implied elasticities are -0.09 using ODS Plans 3 to 5 as the treatment group and -0.15 using ODS Plans 6 to 8 as the comparison group. Thus, these findings provide suggestive evidence that our main results are driven by increase in cost-sharing for low value services and not other general cost-sharing changes at OEBB.

\subsection{Other robustness checks}

We have conducted a number of additional sensitivity checks to further probe the robustness of our findings. More specifically, we have added employer-specific linear time trends (i.e., interact each employer fixed effects with a linear time trend, where we measure time from the beginning of the study period), assigned false start dates for the V-BID program, tested the parallel trends assumption using regression methods (i.e., we interacted a treatment dummy with the linear time trend, and regressed each of our outcomes on this indicator, demographics, employer fixed effects, and year fixed effects using pre-treatment data), and examined the impact of the V-BID on a set of falsification outcomes (i.e., emergency appendectomy, tonsillitis). ${ }^{23}$ Finally, a concern with our analysis is that our treatment group is quite large relative to our comparison group. To explore the impact of this difference in group size, we drew a $10 \%$ random sample of OEBB beneficiaries (to create more equally sized treatment and comparison groups) and re-estimated our regressions. Overall, our findings from these additional checks strongly support the validity of our research design. Additional details are available on request.

\section{Discussion}

In this study, we explore the effect of a value-based insurance design (V-BID) that substantially increased patient cost-sharing for sleep studies, endoscopies, advanced imaging services, and potentially overused surgeries. To the best of our knowledge, we are the first to

\footnotetext{
${ }^{23}$ We chose these services because they reflect medical emergencies; that is a situation in which there is little to no discretion on the part of the consumer whether or not to receive treatment.
} 
study the effect of a V-BID design using increased cost sharing for low value services such as these using a quasi-experimental design. Thus, we offer new insight to the large and growing literature on V-BID programs. This information is timely as V-BID principles are embedded within the Affordable Care Act and are being incorporated into major public insurance systems (e.g., Medicare Advantage); most large employers currently apply V-BID principles, or plan to include these principles, in the near future; and healthcare providers themselves are attempting to reduce the delivery of low value care. Moreover, we contribute to the economic literature that examines the impact of cost-sharing more broadly.

We exploit a novel V-BID implemented by a large public employer in the state of Oregon. We apply a differences-in-differences design to study program impacts, thus our findings have a causal interpretation. A concern with the V-BID literature is that many studies lack a suitable comparison group and therefore it is difficult to disentangle V-BID effects from contemporaneous trends in healthcare use (Look 2015). Moreover, we have access to three years of post-V-BID data which allows us to better track program dynamics than previous studies which rely on shorter study periods. Thus, our analysis represents an important step forward in understanding the potential of V-BIDs to address the high and rising healthcare costs in the U.S. Our findings suggest that this program did indeed increase patient cost-sharing and, in turn, reduced the use of some, but not all, targeted services.

Our study, although novel in many ways, is not without limitations. First, we rely on just one program and four public companies in the state of Oregon. Thus, the generalizability of our findings to other settings is not clear. Second, although we conducted numerous robustness checks to assess the validity of our research design, we cannot definitively rule out the possibility that our findings are driven by some other cost-containment or provider-level changes. Third, it 
is plausible that beneficiaries, in response to the V-BID, simply terminated their employer-based coverage. Fourth, although the OEBB administrators went to great lengths to select low value services, some the services targeted by the V-BID program may be of high value for some patients (e.g., upper gastrointestinal endoscopies can be life-saving when preformed for gastrointestinal bleeding). Thus, we note that the selection of services for increases in costsharing may not be sufficiently nuanced. The lack of a standardized and validated set of services that are lower and higher value is an important barrier for both the research field, and healthcare providers and payers. We encourage future studies to rigorously test healthcare service value to facilitate better research and policy decisions.

The question of how to address high healthcare costs, without undermining patient outcomes, is critical for maintaining the financial stability of governments at the Federal, state, and local level; insurers; and patients and the health of the U.S. population. We provide new insight on this question. Future research could explore the effect of V-BID programs on utilization of a broader set of healthcare services and in different patient populations. 
Table 1: Additional Cost Tier (ACT) services and cost-sharing increases

\begin{tabular}{|c|c|c|c|c|c|}
\hline Variable & Services & $\begin{array}{l}\text { Copayment } \\
\text { change date }\end{array}$ & $\begin{array}{c}\text { Copayment } \\
\text { increase }\end{array}$ & $\begin{array}{c}\text { Coinsurance } \\
\text { change date }\end{array}$ & $\begin{array}{c}\text { Coinsurance } \\
\text { increase }\end{array}$ \\
\hline $\begin{array}{l}\text { Sleep } \\
\text { studies }\end{array}$ & $\begin{array}{l}\text { Home sleep studies; } \\
\text { facility sleep studies }\end{array}$ & October $1^{\text {st }}, 2010$ & $\$ 100$ & October $1^{\text {st }}, 2011$ & $10-20$ ppts* \\
\hline $\begin{array}{l}\text { Upper GI } \\
\text { endoscopy }\end{array}$ & Upper GI endoscopies & $\begin{array}{l}\text { October } 1^{\text {st }}, 2010 \text {; } \\
\text { October } 1^{\text {st }}, 2011\end{array}$ & $\begin{array}{l}\$ 500 \\
\$ 100\end{array}$ & October $1^{\text {st }}, 2010$ & 10-40 ppts* \\
\hline $\begin{array}{l}\text { Advanced } \\
\text { imaging } \\
\text { services }\end{array}$ & CT, MRI, PET & October $1^{\text {st }}, 2010$ & $\$ 100$ & October $1^{\text {st }}, 2011$ & $10-20$ ppts* \\
\hline $\begin{array}{l}\text { Potentially } \\
\text { overused } \\
\text { surgeries }\end{array}$ & $\begin{array}{l}\text { Spine surgeries for } \\
\text { pain; knee and } \\
\text { shoulder arthoscopies; } \\
\text { hip and knee } \\
\text { replacements }\end{array}$ & October $1^{\text {st }}, 2010$ & $\$ 500$ & October $1^{\text {st }}, 2010$ & 10-40 ppts* \\
\hline
\end{tabular}

Notes: OEBB plan year October $1^{\text {st }}$-September $30^{\text {th }}$. Comparison company plan year January $1^{\text {st }}$-December $31^{\text {st }}$. ppts=percentage points.

*Coinsurance increase depends on plan. 
Table 2. Summary statistics: Pre-treatment period (October $1^{\text {st }}, 2008$ to September $\left.31^{\text {st }}, 2010\right)$

\begin{tabular}{|c|c|c|c|}
\hline Sample: & OEBB & $\begin{array}{l}\text { Comparison } \\
\text { companies } \dagger\end{array}$ & $\begin{array}{c}\text { Difference } \dagger \dagger \\
\text { (p-value) }\end{array}$ \\
\hline \multicolumn{4}{|l|}{ ACT services: OOP payments* } \\
\hline Sleep study & 284.764 & 104.382 & 0.0000 \\
\hline Endoscopy & 160.412 & 98.4644 & 0.0000 \\
\hline Advanced imaging & 195.244 & 64.9788 & 0.0000 \\
\hline Potentially overused surgeries $\dagger+\dagger$ & 339.480 & 202.632 & 0.0000 \\
\hline Any ACT & 210.959 & 87.5820 & 0.0000 \\
\hline \multicolumn{4}{|l|}{ ACT services: Any use } \\
\hline Sleep study & 0.0014170 & 0.0014531 & 0.7811 \\
\hline Endoscopy & 0.0013626 & 0.0017222 & 0.0053 \\
\hline Advanced imaging & 0.011989 & 0.014682 & 0.0000 \\
\hline Potentially overused surgeries $\dagger+\dagger$ & 0.0024577 & 0.0031430 & 0.0001 \\
\hline Any ACT & 0.016685 & 0.020247 & 0.0000 \\
\hline \multicolumn{4}{|l|}{ ACT services: Episodes } \\
\hline Sleep study & 0.0023385 & 0.0017545 & 0.0108 \\
\hline Endoscopy & 0.0024855 & 0.0032830 & 0.0010 \\
\hline Advanced imaging & 0.020250 & 0.026565 & 0.0000 \\
\hline Potentially overused surgeries $\dagger \dagger \dagger$ & 0.0051215 & 0.0056295 & 0.1741 \\
\hline Any ACT & 0.042102 & 0.057210 & 0.0000 \\
\hline \multicolumn{4}{|l|}{ Demographics } \\
\hline Age & 46.3610 & 44.9315 & 0.0000 \\
\hline Male & 0.42062 & 0.47145 & 0.0000 \\
\hline Female & 0.57938 & 0.52855 & 0.0000 \\
\hline Employee & 0.60675 & 0.61069 & 0.0192 \\
\hline Spouse & 0.32857 & 0.34229 & 0.0000 \\
\hline Child & 0.064681 & 0.047016 & 0.0000 \\
\hline Observations (total) & 863808 & 92904 & -- \\
\hline
\end{tabular}

Notes: The unit of observation is a beneficiary/month/year.

*OOP=copayments + coinsurance. Conditional on using the specific service.

†Comparison companies include Portland General Electric, Washington County, and Clackamas County.

††Difference between OEBB and comparison companies calculated with a $t$-test for continuous variables and a chisquared test for binary variables.

$\dagger \dagger \dagger$ Potentially overused surgeries = Spine surgeries for pain; knee and shoulder arthoscopies; and hip and knee replacements. 
Table 3. Effect of VIBD on ACT service OOP payments conditional on service use, any utilization of ACT services, and the number of ACT services

\begin{tabular}{|c|c|c|c|c|c|}
\hline Outcome: & $\begin{array}{c}\text { Sleep } \\
\text { studies }\end{array}$ & Endoscopy & $\begin{array}{c}\text { Advanced } \\
\text { imaging } \\
\end{array}$ & $\begin{array}{c}\text { Potentially } \\
\text { overused } \\
\text { surgeries } \dagger\end{array}$ & Any ACT \\
\hline $\begin{array}{l}\text { Panel A:OOP } \\
\text { payments }\end{array}$ & 284.7639 & 160.4122 & 195.2439 & 339.4799 & 210.9595 \\
\hline $\begin{array}{l}\text { OEBB proportion, } \\
\text { pre-treatment }\end{array}$ & 284.7639 & 160.4122 & 195.2439 & 339.4799 & 210.9595 \\
\hline DD & $\begin{array}{c}129.62145 * * * \\
(19.62929)\end{array}$ & $\begin{array}{c}244.75335 * * * \\
(17.39088)\end{array}$ & $\begin{array}{c}142.82070 * * * \\
(5.59717)\end{array}$ & $\begin{array}{c}540.59854 * * * \\
(27.74835)\end{array}$ & $\begin{array}{c}211.66962 * * * \\
(7.10371)\end{array}$ \\
\hline Observations & 3172 & 3127 & 29126 & 6337 & 40440 \\
\hline \multicolumn{6}{|l|}{$\begin{array}{l}\text { Panel B: Any } \\
\text { utilization }\end{array}$} \\
\hline $\begin{array}{l}\text { OEBB proportion, } \\
\text { pre-treatment }\end{array}$ & 0.0014 & 0.0014 & 0.0120 & 0.0025 & 0.0167 \\
\hline DD & $\begin{array}{c}-0.00033^{* * *} \\
(0.00012)\end{array}$ & $\begin{array}{l}-0.00017 \\
(0.00011)\end{array}$ & $\begin{array}{c}-0.00092 * * * \\
(0.00034)\end{array}$ & $\begin{array}{c}-0.00061 * * * \\
(0.00017)\end{array}$ & $\begin{array}{c}-0.00199 * * * \\
(0.00041)\end{array}$ \\
\hline Observations & 2391780 & 2391780 & 2391780 & 2391780 & 2391780 \\
\hline$\varepsilon \dagger \dagger$ & -0.5178 & -0.0796 & -0.1048 & -0.1532 & -0.1188 \\
\hline \multicolumn{6}{|l|}{$\begin{array}{l}\text { Panel C: Number of } \\
\text { services }\end{array}$} \\
\hline $\begin{array}{l}\text { OEBB mean, pre- } \\
\text { treatment }\end{array}$ & 0.0023 & 0.0025 & 0.0202 & 0.0051 & 0.0421 \\
\hline DD & $\begin{array}{c}-0.00073^{* * *} \\
(0.00019) \\
\end{array}$ & $\begin{array}{l}-0.00027 \\
(0.00021)\end{array}$ & $\begin{array}{c}-0.00127 * * \\
(0.00063)\end{array}$ & $\begin{array}{c}-0.00135 * * * \\
(0.00034) \\
\end{array}$ & $\begin{array}{c}-0.00548 * * * \\
(0.00141) \\
\end{array}$ \\
\hline Observations & 2391780 & 2391780 & 2391780 & 2391780 & 2391780 \\
\hline$\varepsilon \dagger \dagger$ & -0.6973 & -0.0708 & -0.0859 & -0.1662 & -0.1297 \\
\hline
\end{tabular}

Notes: All models estimated with OLS and control for beneficiary characteristics reported in Table 2, and employer, month, and year fixed effects. Robust standard errors reported in parentheses. The study period is October $1^{\text {st }}, 2008$ to September $30^{\text {th }}$, 2013. The unit of observation is a beneficiary/month/year. See Table 1 for cost-sharing increases. $\mathrm{OOP}=$ copayment + coinsurance.

†Potentially overused surgeries=Spine surgeries for pain; knee and shoulder arthoscopies; and hip and knee replacements.

$\dagger \dagger \varepsilon=$ (percent change quantity $) /($ percent change price $)=\left(\beta_{Q} /\right.$ mean in service use in pre-treatment period at OEBB $) /\left(\beta_{O O P} /\right.$ mean OOP payment in pre-treatment period at OEBB). $\beta_{O O P}$ reported in Panel A.

$* * * ; * *=$ statistically different from zero at the $1 \%$; $5 \%$ level. 
Table 4. Effect of VIBD on ACT service OOP payments conditional on service use, any utilization of ACT services, and the number of ACT services: Allowing for program dynamics

\begin{tabular}{|c|c|c|c|c|c|}
\hline Outcome: & $\begin{array}{l}\text { Sleep } \\
\text { studies }\end{array}$ & Endoscopy & $\begin{array}{c}\text { Advanced } \\
\text { imaging }\end{array}$ & $\begin{array}{c}\text { Potentially } \\
\text { overused } \\
\text { surgeries } \dagger\end{array}$ & Any ACT \\
\hline \multicolumn{6}{|l|}{$\begin{array}{l}\text { Panel A:OOP } \\
\text { payments }\end{array}$} \\
\hline $\begin{array}{l}\text { OEBB mean, pre- } \\
\text { treatment }\end{array}$ & 284.7639 & 160.4122 & 195.2439 & 339.4799 & 210.9595 \\
\hline 2 years pre V-BID & $\begin{array}{c}-1.27081 \\
(33.22246)\end{array}$ & $\begin{array}{l}17.25940 \\
(29.15299)\end{array}$ & $\begin{array}{l}13.08937 \\
(7.65846)\end{array}$ & $\begin{array}{c}6.67340 \\
(43.52239)\end{array}$ & $\begin{array}{c}8.19912 \\
(9.16980)\end{array}$ \\
\hline $\begin{array}{l}\text { V-BID } \\
\text { implementation year }\end{array}$ & $\begin{array}{c}100.48071^{* * *} \\
(34.06320)\end{array}$ & $\begin{array}{c}269.07538 * * * \\
(33.05739)\end{array}$ & $\begin{array}{c}136.36382 * * * \\
(8.07614)\end{array}$ & $\begin{array}{c}482.53135^{* * *} \\
(49.07449)\end{array}$ & $\begin{array}{c}198.75756^{* * * *} \\
(10.99591)\end{array}$ \\
\hline 1 years post V-BID & $\begin{array}{c}86.53260 * * * \\
(31.89076)\end{array}$ & $\begin{array}{c}121.10513^{* * *} \\
(33.41409)\end{array}$ & $\begin{array}{c}125.49575^{* * * *} \\
(7.65844)\end{array}$ & $\begin{array}{c}451.47530^{* * * *} \\
(44.10162)\end{array}$ & $\begin{array}{c}175.45673^{* * *} \\
(10.68414)\end{array}$ \\
\hline 2 years post V-BID & $\begin{array}{l}12.66015 \\
(34.82620)\end{array}$ & $\begin{array}{c}\text { 73.28946** } \\
(30.01159)\end{array}$ & $\begin{array}{c}100.22736^{* * *} \\
(7.92333)\end{array}$ & $\begin{array}{c}413.15973 * * * \\
(47.44504)\end{array}$ & $\begin{array}{c}145.34314^{* * *} \\
(11.26655)\end{array}$ \\
\hline Observations & 3172 & 3127 & 29126 & 6337 & 40440 \\
\hline \multicolumn{6}{|l|}{$\begin{array}{l}\text { Panel B: Any } \\
\text { utilization }\end{array}$} \\
\hline $\begin{array}{l}\text { OEBB mean, pre- } \\
\text { treatment }\end{array}$ & 0.0014 & 0.0014 & 0.0120 & 0.0025 & 0.0167 \\
\hline 2 years pre V-BID & $\begin{array}{l}-0.00036 \\
(0.00026)\end{array}$ & $\begin{array}{l}-0.00027 \\
(0.00028)\end{array}$ & $\begin{array}{c}0.00002 \\
(0.00082)\end{array}$ & $\begin{array}{l}-0.00010 \\
(0.00038)\end{array}$ & $\begin{array}{l}-0.00046 \\
(0.00096)\end{array}$ \\
\hline $\begin{array}{l}\text { V-BID } \\
\text { implementation year }\end{array}$ & $\begin{array}{c}-0.00052^{* *} \\
(0.00026)\end{array}$ & $\begin{array}{l}-0.00021 \\
(0.00027)\end{array}$ & $\begin{array}{l}-0.00165^{* *} \\
(0.00083)\end{array}$ & $\begin{array}{l}-0.00042 \\
(0.00040)\end{array}$ & $\begin{array}{c}-0.00268 * * * \\
(0.00097)\end{array}$ \\
\hline 1 years post V-BID & $\begin{array}{c}-0.00101^{* * * *} \\
(0.00028)\end{array}$ & $\begin{array}{c}0.00019 \\
(0.00027)\end{array}$ & $\begin{array}{c}-0.00198 * * \\
(0.00084)\end{array}$ & $\begin{array}{c}-0.00182^{* * *} \\
(0.00044)\end{array}$ & $\begin{array}{c}-0.00440 * * * \\
(0.00100)\end{array}$ \\
\hline 2 years post V-BID & $\begin{array}{c}-0.00083^{* * *} \\
(0.00027)\end{array}$ & $\begin{array}{l}-0.00020 \\
(0.00028)\end{array}$ & $\begin{array}{l}-0.00074 \\
(0.00083)\end{array}$ & $\begin{array}{c}-0.00110 * * * \\
(0.00042)\end{array}$ & $\begin{array}{c}-0.00266^{* * *} \\
(0.00099)\end{array}$ \\
\hline Observations & 2391780 & 2391780 & 2391780 & 2391780 & 2391780 \\
\hline \multicolumn{6}{|l|}{$\begin{array}{l}\text { Panel C: Number of } \\
\text { services }\end{array}$} \\
\hline $\begin{array}{l}\text { OEBB mean, pre- } \\
\text { treatment }\end{array}$ & 0.0023 & 0.0025 & 0.0202 & 0.0051 & 0.0421 \\
\hline 2 years pre V-BID & $\begin{array}{l}-0.00045 \\
(0.00035)\end{array}$ & $\begin{array}{l}-0.00050 \\
(0.00055)\end{array}$ & $\begin{array}{l}-0.00069 \\
(0.00158)\end{array}$ & $\begin{array}{l}-0.00026 \\
(0.00073)\end{array}$ & $\begin{array}{l}-0.00329 \\
(0.00347)\end{array}$ \\
\hline $\begin{array}{l}\text { V-BID } \\
\text { implementation year }\end{array}$ & $\begin{array}{c}-0.00086^{* *} \\
(0.00035)\end{array}$ & $\begin{array}{l}-0.00041 \\
(0.00053)\end{array}$ & $\begin{array}{l}-0.00285 \\
(0.00156)\end{array}$ & $\begin{array}{l}-0.00140 \\
(0.00077)\end{array}$ & $\begin{array}{c}-0.01068^{* * * *} \\
(0.00396)\end{array}$ \\
\hline 1 years post V-BID & $\begin{array}{c}-0.00190^{* * *} \\
(0.00041)\end{array}$ & $\begin{array}{c}0.00042 \\
(0.00051)\end{array}$ & $\begin{array}{l}-0.00311^{* *} \\
(0.00157)\end{array}$ & $\begin{array}{c}-0.00416 * * * \\
(0.00085)\end{array}$ & $\begin{array}{l}-0.01756^{* * *} \\
(0.00405)\end{array}$ \\
\hline 2 years post V-BID & $\begin{array}{c}-0.00182^{* * * *} \\
(0.00041)\end{array}$ & $\begin{array}{l}-0.00036 \\
(0.00054)\end{array}$ & $\begin{array}{l}-0.00027 \\
(0.00155)\end{array}$ & $\begin{array}{c}-0.00272 * * * \\
(0.00081)\end{array}$ & $\begin{array}{c}-0.00898 * * \\
(0.00361)\end{array}$ \\
\hline Observations & 2391780 & 2391780 & 2391780 & 2391780 & 2391780 \\
\hline $\begin{array}{l}\text { Notes: All models est } \\
\text { month, and year fixed } \\
\text { to September } 30^{\text {th }}, 20 \\
\text { increases. OOP=copa } \\
\text { †Potentially overused } \\
\text { replacements. } \\
* * * ; * *=\text { statistically di }\end{array}$ & $\begin{array}{l}\text { ated with OLS } \\
\text { ects. Robust st } \\
\text { The unit of obs } \\
\text { ent+coinsurance } \\
\text { geries=Spine st } \\
\text { rent from zero }\end{array}$ & $\begin{array}{l}\text { control for ben } \\
\text { ard errors repor } \\
\text { ation is a benef } \\
\text { ries for pain; } k \\
\text { e } 1 \% \text {; } 5 \% \text { level }\end{array}$ & $\begin{array}{l}\text { iary characteris } \\
\text { in parentheses } \\
\text { ry/month/year. } \\
\text { and shoulder a }\end{array}$ & $\begin{array}{l}\text { ics reported in Ta } \\
\text { The study perioc } \\
\text { See Table } 1 \text { for } \\
\text { thoscopies; and h }\end{array}$ & $\begin{array}{l}\text { le 2, and employ } \\
\text { s October } 1^{\text {st }}, 20 \\
\text { st-sharing } \\
\text { and knee }\end{array}$ \\
\hline
\end{tabular}


Appendix Table A. Share of OEBB beneficiaries covered by Moda Health

\begin{tabular}{ll}
\hline \hline Plan year & Share \\
\hline 2008 & 0.682 \\
2009 & 0.725 \\
2010 & 0.767 \\
2011 & 0.790 \\
2012 & 0.802 \\
\hline Full period & 0.753 \\
\hline
\end{tabular}

Notes: OEBB beneficiaries were covered by three different insurers: OEBB (for which we have data), Kaiser Permanente, Providence Health. We have access to all Moda Health data. The source of these data are OEBB annual reports. More details available on request from the corresponding author.

Appendix Table B. Comparison of the balanced and unbalanced panels

\begin{tabular}{lccc}
\hline Sample: & $\begin{array}{c}\text { Balanced } \\
\text { panel }\end{array}$ & $\begin{array}{c}\text { Unbalanced } \\
\text { panel }\end{array}$ & $\begin{array}{c}\text { Difference } \dagger \\
\text { (p-value) }\end{array}$ \\
\hline Demographics & & & \\
\hline Age & 47.7222 & 44.7506 & 0.0000 \\
Male & 0.42556 & 0.44374 & 0.0000 \\
Female & 0.57444 & 0.55626 & 0.0000 \\
Employee & 0.60713 & 0.52416 & 0.0000 \\
Spouse & 0.32990 & 0.31453 & 0.0000 \\
Child & 0.062966 & 0.16131 & 0.0000 \\
\hline Observations & 2391780 & 4672864 & -- \\
\hline
\end{tabular}

Notes: The unit of observation is a beneficiary/month/year.

*OOP=copayments +coinsurance. Conditional on using the specific service.

†Difference between OEBB and comparison companies calculated with a $t$-test for continuous variables and a chisquared test for binary variables.

Appendix Table C. Effect of VIBD on ACT service unconditional OOP payments

\begin{tabular}{lccccc}
\hline \hline Outcome: & $\begin{array}{c}\text { Sleep } \\
\text { studies }\end{array}$ & Endoscopy & $\begin{array}{c}\text { Advanced } \\
\text { imaging }\end{array}$ & $\begin{array}{c}\text { Potentially } \\
\text { overused } \\
\text { surgeries } \dagger\end{array}$ & Any ACT \\
\hline OEBB proportion, & 0.4224 & 0.3157 & 2.9148 & 1.6392 & 5.1028 \\
pre-treatment & & & & & \\
\hline DD & $0.11271^{* *}$ & $0.25321^{* * *}$ & $1.55348^{* * *}$ & $1.28953^{* * *}$ & $3.10041^{* * *}$ \\
& $(0.04515)$ & $(0.03655)$ & $(0.10451)$ & $(0.13250)$ & $(0.17106)$ \\
\hline Observations & 2391780 & 2391780 & 2391780 & 2391780 & 2391780 \\
\hline
\end{tabular}

Notes: All models estimated with OLS and control for beneficiary characteristics reported in Table 2, and employer, month, plan, and year fixed effects. Robust standard errors reported in parentheses. The study period is October $1^{\text {st }}$, 2008 to September $30^{\text {th }}$, 2013. The unit of observation is a beneficiary/month/year. See Table 1 for cost-sharing increases. OOP=copayment + coinsurance.

$\dagger$ Potentially overused surgeries=Spine surgeries for pain; knee and shoulder arthoscopies; and hip and knee replacements.

$* * * ; * *=$ statistically different from zero at the $1 \% ; 5 \%$ level. 
Appendix Table D1. Effect of VIBD on ACT service OOP payments conditional on service use: Full set of coefficient estimates

\begin{tabular}{|c|c|c|c|c|c|}
\hline Outcome: & $\begin{array}{l}\text { Sleep } \\
\text { studies }\end{array}$ & Endoscopy & $\begin{array}{c}\text { Advanced } \\
\text { imaging }\end{array}$ & $\begin{array}{c}\text { Potentially } \\
\text { overused } \\
\text { surgeries } \dagger\end{array}$ & Any ACT \\
\hline $\begin{array}{l}\text { OEBB proportion, } \\
\text { pre-treatment }\end{array}$ & 284.7639 & 160.4122 & 195.2439 & 339.4799 & 210.9595 \\
\hline DD & $\begin{array}{c}129.62145^{* * *} \\
(19.62929)\end{array}$ & $\begin{array}{c}244.75335 * * * \\
(17.39088)\end{array}$ & $\begin{array}{c}142.82070 * * * \\
(5.59717)\end{array}$ & $\begin{array}{c}540.59854 * * * \\
(27.74835)\end{array}$ & $\begin{array}{c}211.66962 * * * \\
(7.10371)\end{array}$ \\
\hline Age & $\begin{array}{c}-1.17757 * * \\
(0.56640)\end{array}$ & $\begin{array}{l}-0.87479 * * \\
(0.41000)\end{array}$ & $\begin{array}{l}-0.30258 \\
(0.15583)\end{array}$ & $\begin{array}{c}-2.15158 * * \\
(0.89883)\end{array}$ & $\begin{array}{c}0.15682 \\
(0.20002)\end{array}$ \\
\hline Female & $\begin{array}{l}-4.43928 \\
(9.42465)\end{array}$ & $\begin{array}{c}21.44824^{* * *} \\
(7.55054)\end{array}$ & $\begin{array}{l}-0.81504 \\
(2.74027)\end{array}$ & $\begin{array}{c}-52.92452 * * * \\
(13.73458)\end{array}$ & $\begin{array}{c}-25.72340 * * * \\
(3.50479)\end{array}$ \\
\hline Spouse & $\begin{array}{l}-7.55369 \\
(9.93557)\end{array}$ & $\begin{array}{l}-1.50049 \\
(7.76253)\end{array}$ & $\begin{array}{l}-1.53799 \\
(2.84518)\end{array}$ & $\begin{array}{l}-22.26688 \\
(14.33850)\end{array}$ & $\begin{array}{l}-7.16585 * * \\
(3.61972)\end{array}$ \\
\hline Child & $\begin{array}{l}-21.02143 \\
(46.69283)\end{array}$ & $\begin{array}{c}5.95448 \\
(23.32105)\end{array}$ & $\begin{array}{l}-4.09508 \\
(9.62118)\end{array}$ & $\begin{array}{l}-4.98086 \\
(51.79300)\end{array}$ & $\begin{array}{l}-17.81481 \\
(10.89919)\end{array}$ \\
\hline 2009 & $\begin{array}{c}1.98606 \\
(23.22963)\end{array}$ & $\begin{array}{l}-21.73485 \\
(16.95807)\end{array}$ & $\begin{array}{l}-9.28022 \\
(6.66981)\end{array}$ & $\begin{array}{c}53.79539 \\
(29.74836)\end{array}$ & $\begin{array}{l}-0.74603 \\
(6.90900)\end{array}$ \\
\hline 2010 & $\begin{array}{l}-20.45794 \\
(23.64047)\end{array}$ & $\begin{array}{c}-3.80032 \\
(18.21414)\end{array}$ & $\begin{array}{c}-13.82754 * * \\
(6.89932)\end{array}$ & $\begin{array}{c}57.52737 \\
(30.50199)\end{array}$ & $\begin{array}{c}1.02540 \\
(7.29417)\end{array}$ \\
\hline 2011 & $\begin{array}{c}18.29272 \\
(30.13531)\end{array}$ & $\begin{array}{l}21.23830 \\
(24.38408)\end{array}$ & $\begin{array}{c}-31.20398 * * * \\
(8.56659)\end{array}$ & $\begin{array}{l}90.12082 * * \\
(41.72693)\end{array}$ & $\begin{array}{l}-1.86080 \\
(10.12951)\end{array}$ \\
\hline 2012 & $\begin{array}{l}-19.33808 \\
(29.85878)\end{array}$ & $\begin{array}{c}-145.1135^{* * * *} \\
(24.06675)\end{array}$ & $\begin{array}{c}-34.72265 * * * \\
(8.52983)\end{array}$ & $\begin{array}{c}49.26046 \\
(41.38945)\end{array}$ & $\begin{array}{l}-11.38911 \\
(10.20645)\end{array}$ \\
\hline 2013 & $\begin{array}{c}-89.48896 * * * \\
(32.76456)\end{array}$ & $\begin{array}{c}-142.7563 * * * \\
(25.38749)\end{array}$ & $\begin{array}{c}-51.19993 * * * \\
(9.10100)\end{array}$ & $\begin{array}{c}83.99680 \\
(45.53722)\end{array}$ & $\begin{array}{l}-25.45109 * * \\
(11.06644)\end{array}$ \\
\hline February & $\begin{array}{c}25.16468 \\
(23.43574)\end{array}$ & $\begin{array}{l}-16.23868 \\
(17.63998)\end{array}$ & $\begin{array}{l}-11.82881 \\
(6.57639)\end{array}$ & $\begin{array}{l}-38.09287 \\
(32.10652)\end{array}$ & $\begin{array}{l}-11.45951 \\
(8.23108)\end{array}$ \\
\hline March & $\begin{array}{c}1.24322 \\
(21.00357)\end{array}$ & $\begin{array}{c}-48.12820 * * * \\
(16.12436)\end{array}$ & $\begin{array}{c}-17.55753 * * * \\
(6.36398)\end{array}$ & $\begin{array}{l}-61.15385 \\
(31.90285)\end{array}$ & $\begin{array}{c}-22.23695 * * * \\
(7.97904)\end{array}$ \\
\hline April & $\begin{array}{c}2.99932 \\
(20.96103)\end{array}$ & $\begin{array}{l}-11.05947 \\
(17.57518)\end{array}$ & $\begin{array}{c}-16.61506^{* *} \\
(6.50234)\end{array}$ & $\begin{array}{c}-92.11341 * * * \\
(33.19739)\end{array}$ & $\begin{array}{c}-25.57896 * * * \\
(8.09477)\end{array}$ \\
\hline May & $\begin{array}{l}-42.20496 \\
(22.38354)\end{array}$ & $\begin{array}{l}-29.92143 \\
(16.57424)\end{array}$ & $\begin{array}{c}-21.81998 * * * \\
(6.38206)\end{array}$ & $\begin{array}{c}-83.34243^{* *} \\
(33.23898)\end{array}$ & $\begin{array}{c}-27.66129 * * * \\
(8.19184)\end{array}$ \\
\hline June & $\begin{array}{l}-13.42005 \\
(22.25227)\end{array}$ & $\begin{array}{c}-41.95525 * * \\
(17.07620)\end{array}$ & $\begin{array}{c}-27.17208^{* * *} \\
(6.21003)\end{array}$ & $\begin{array}{c}-1.18 \mathrm{e}+02^{* * *} \\
(30.71899)\end{array}$ & $\begin{array}{c}-35.49104 * * * \\
(7.84621)\end{array}$ \\
\hline July & $\begin{array}{c}0.13001 \\
(21.91400)\end{array}$ & $\begin{array}{l}-29.67478 \\
(16.32409)\end{array}$ & $\begin{array}{c}-24.60718^{* * *} \\
(6.61926)\end{array}$ & $\begin{array}{c}-1.15 \mathrm{e}+02^{* * *} \\
(31.50945)\end{array}$ & $\begin{array}{c}-27.42087 * * * \\
(8.14907)\end{array}$ \\
\hline August & $\begin{array}{l}-22.67075 \\
(20.16237)\end{array}$ & $\begin{array}{c}-47.34005^{* * *} \\
(16.65532)\end{array}$ & $\begin{array}{c}-36.11367 * * * \\
(6.20240)\end{array}$ & $\begin{array}{c}-1.26 \mathrm{e}+02^{* * *} \\
(31.17390)\end{array}$ & $\begin{array}{c}-42.06062 * * * \\
(7.83654)\end{array}$ \\
\hline September & $\begin{array}{l}-25.31747 \\
(19.67963)\end{array}$ & $\begin{array}{c}-66.26329 * * * \\
(16.44578)\end{array}$ & $\begin{array}{c}-29.69990 * * * \\
(6.40130)\end{array}$ & $\begin{array}{c}-1.75 \mathrm{e}+02 * * * \\
(31.39272)\end{array}$ & $\begin{array}{c}-48.07220^{* * *} \\
(7.75405)\end{array}$ \\
\hline October & $\begin{array}{c}8.43610 \\
(23.57300)\end{array}$ & $\begin{array}{c}-67.75516^{* * *} \\
(19.46572)\end{array}$ & $\begin{array}{l}-13.02620 \\
(7.39542)\end{array}$ & $\begin{array}{l}-55.52498 \\
(42.24872)\end{array}$ & $\begin{array}{c}-28.91398 * * * \\
(9.24279)\end{array}$ \\
\hline November & $\begin{array}{c}19.64731 \\
(22.97677)\end{array}$ & $\begin{array}{c}-39.02285^{* *} \\
(18.42423)\end{array}$ & $\begin{array}{l}-9.54187 \\
(7.17485)\end{array}$ & $\begin{array}{c}39.25203 \\
(37.00749)\end{array}$ & $\begin{array}{l}-6.49585 \\
(8.99796)\end{array}$ \\
\hline December & $\begin{array}{c}30.47927 \\
(25.13474)\end{array}$ & $\begin{array}{c}-54.52918 * * * \\
(18.22065)\end{array}$ & $\begin{array}{l}-10.48986 \\
(6.99550)\end{array}$ & $\begin{array}{c}10.45729 \\
(32.55854)\end{array}$ & $\begin{array}{l}10.43231 \\
(8.96157)\end{array}$ \\
\hline PGE & $\begin{array}{l}-13.89477 \\
(19.88659)\end{array}$ & $\begin{array}{c}64.85213 * * * \\
(24.13668)\end{array}$ & $\begin{array}{c}-8.05056^{* *} \\
(3.74775)\end{array}$ & $\begin{array}{c}191.59170^{* * * *} \\
(27.73687)\end{array}$ & $\begin{array}{c}29.19174 * * * \\
(6.45004)\end{array}$ \\
\hline $\begin{array}{l}\text { Washington } \\
\text { County }\end{array}$ & $\begin{array}{c}177.49616^{* * * *} \\
(25.96387)\end{array}$ & $\begin{array}{c}85.20547 * * * \\
(23.94961)\end{array}$ & $\begin{array}{c}106.45654^{* * * *} \\
(5.56253)\end{array}$ & $\begin{array}{c}230.75160^{* * *} \\
(31.83716)\end{array}$ & $\begin{array}{c}125.61171^{* * *} \\
(7.18786)\end{array}$ \\
\hline $\begin{array}{l}\text { Clackamas } \\
\text { County }\end{array}$ & $\begin{array}{c}206.91946 * * * \\
(20.54002)\end{array}$ & $\begin{array}{c}67.77068 * * * \\
(20.46473)\end{array}$ & $\begin{array}{c}149.50307^{* * *} \\
(4.90643)\end{array}$ & $\begin{array}{c}252.18760 * * * \\
(26.02328)\end{array}$ & $\begin{array}{c}156.78005^{* * * *} \\
(6.19019)\end{array}$ \\
\hline Constant & $152.64080^{* * *}$ & $173.36178 * * *$ & $90.15545^{* * *}$ & $252.92535 * * *$ & $87.01199 * * *$ \\
\hline
\end{tabular}




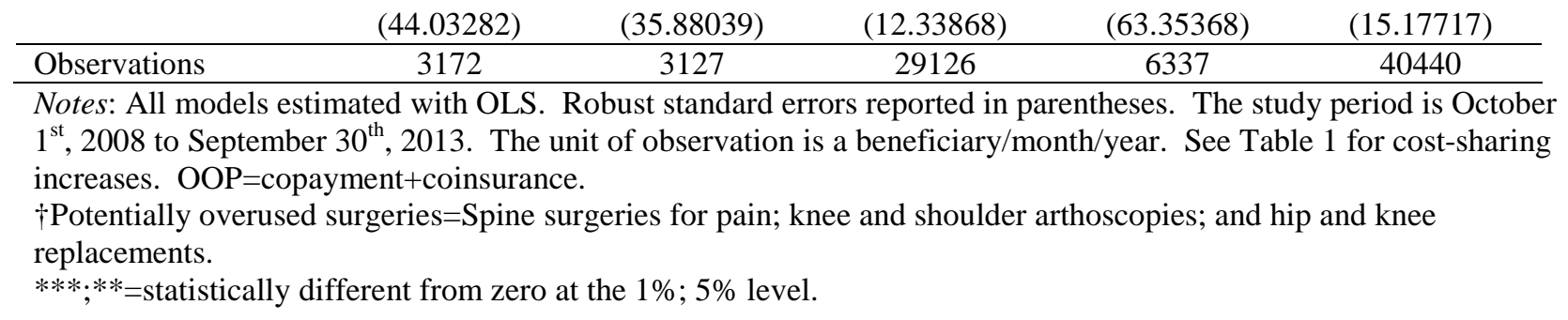


Appendix Table D2. Effect of VIBD on any utilization of ACT services: Full set of coefficient estimates

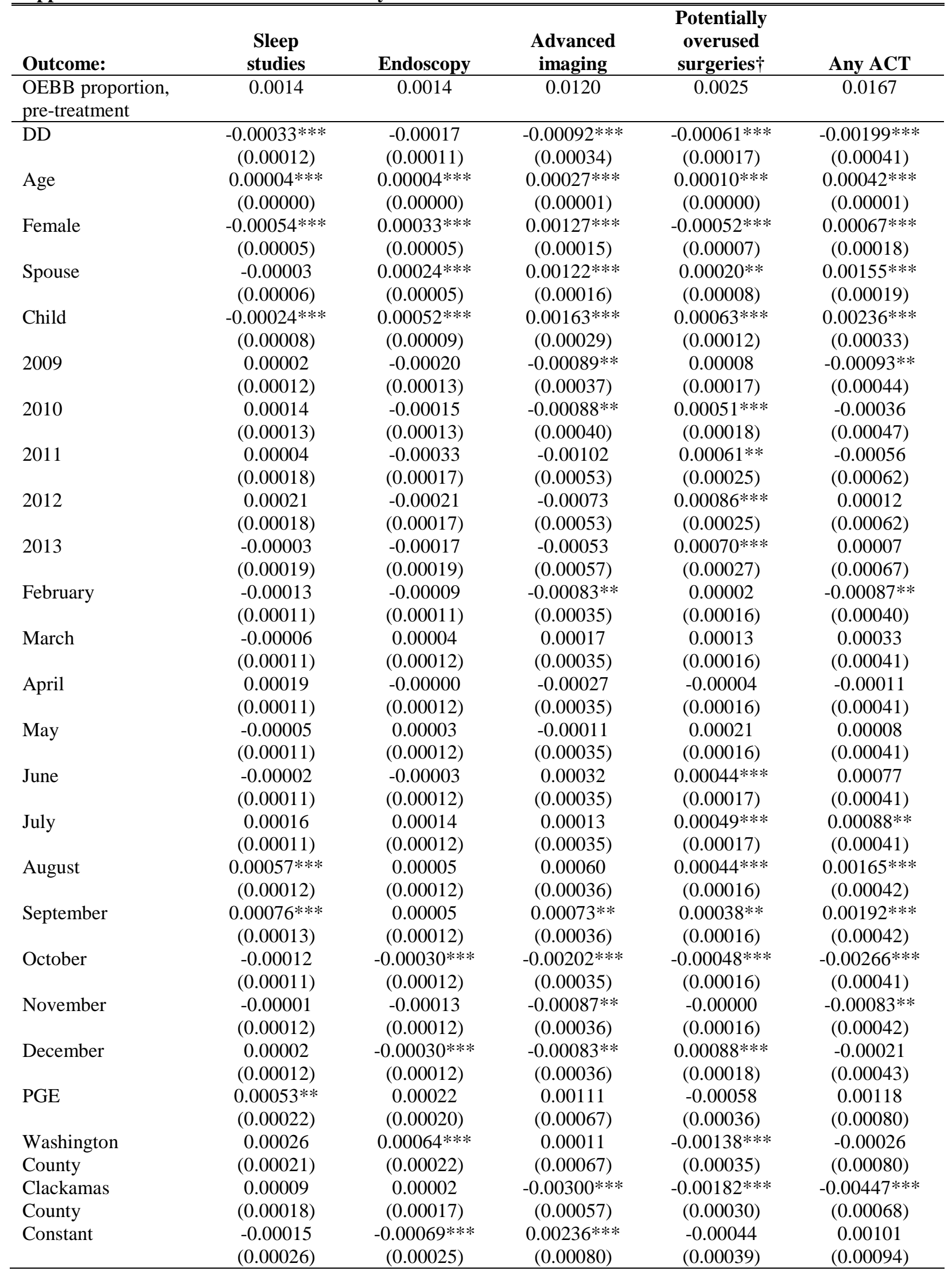


Observations

2391780

2391780

2391780

2391780

2391780

Notes: All models estimated with OLS. Robust standard errors reported in parentheses. The study period is October $1^{\text {st }}, 2008$ to September $30^{\text {th }}, 2013$. The unit of observation is a beneficiary/month/year.

†Potentially overused surgeries=Spine surgeries for pain; knee and shoulder arthoscopies; and hip and knee replacements.

$* * * ; * *=$ statistically different from zero at the 1\%; $5 \%$ level. 
Appendix Table D3. Effect of VIBD on the number of ACT services: Full set of coefficient estimates

\begin{tabular}{|c|c|c|c|c|c|}
\hline Outcome: & $\begin{array}{c}\text { Sleep } \\
\text { studies }\end{array}$ & Endoscopy & $\begin{array}{c}\text { Advanced } \\
\text { imaging }\end{array}$ & $\begin{array}{c}\text { Potentially } \\
\text { overused } \\
\text { surgeries } \dagger \\
\end{array}$ & Any ACT \\
\hline $\begin{array}{l}\text { OEBB mean, pre- } \\
\text { treatment }\end{array}$ & 0.0023 & 0.0025 & 0.0202 & 0.0051 & 0.0421 \\
\hline $\mathrm{DD}$ & $\begin{array}{c}-0.00073^{* * *} \\
(0.00019)\end{array}$ & $\begin{array}{l}-0.00027 \\
(0.00021)\end{array}$ & $\begin{array}{c}-0.00127^{* *} \\
(0.00063)\end{array}$ & $\begin{array}{c}-0.00135 * * * \\
(0.00034)\end{array}$ & $\begin{array}{c}-0.00548 * * * \\
(0.00141)\end{array}$ \\
\hline Age & $\begin{array}{c}0.00006^{* * *} \\
(0.00000)\end{array}$ & $\begin{array}{c}0.00007^{* * *} \\
(0.00000)\end{array}$ & $\begin{array}{c}0.00047 * * * \\
(0.00001)\end{array}$ & $\begin{array}{c}0.00018 * * * \\
(0.00001)\end{array}$ & $\begin{array}{c}0.00111 * * * \\
(0.00003)\end{array}$ \\
\hline Female & $\begin{array}{c}-0.00074^{* * *} \\
(0.00009)\end{array}$ & $\begin{array}{c}0.00071^{* * *} \\
(0.00009)\end{array}$ & $\begin{array}{c}0.00222 * * * \\
(0.00027)\end{array}$ & $\begin{array}{c}-0.00109 * * * \\
(0.00015)\end{array}$ & $\begin{array}{c}0.00067 \\
(0.00056)\end{array}$ \\
\hline Spouse & $\begin{array}{l}-0.00004 \\
(0.00009)\end{array}$ & $\begin{array}{c}0.00039 * * * \\
(0.00010)\end{array}$ & $\begin{array}{c}0.00201 * * * \\
(0.00030)\end{array}$ & $\begin{array}{c}0.00027 \\
(0.00016)\end{array}$ & $\begin{array}{c}0.00437 * * * \\
(0.00062)\end{array}$ \\
\hline Child & $\begin{array}{c}-0.00034^{* *} \\
(0.00013)\end{array}$ & $\begin{array}{c}0.00087 * * * \\
(0.00018)\end{array}$ & $\begin{array}{c}0.00327 * * * \\
(0.00053)\end{array}$ & $\begin{array}{c}0.00114 * * * \\
(0.00025)\end{array}$ & $\begin{array}{c}0.00845 * * * \\
(0.00100)\end{array}$ \\
\hline 2009 & $\begin{array}{c}0.00002 \\
(0.00021)\end{array}$ & $\begin{array}{l}-0.00037 \\
(0.00024)\end{array}$ & $\begin{array}{l}-0.00134 \\
(0.00069)\end{array}$ & $\begin{array}{c}0.00005 \\
(0.00036)\end{array}$ & $\begin{array}{l}-0.00249 \\
(0.00141)\end{array}$ \\
\hline 2010 & $\begin{array}{c}0.00015 \\
(0.00023)\end{array}$ & $\begin{array}{l}-0.00028 \\
(0.00025)\end{array}$ & $\begin{array}{l}-0.00137 \\
(0.00074)\end{array}$ & $\begin{array}{l}0.00082 * * \\
(0.00039)\end{array}$ & $\begin{array}{l}-0.00096 \\
(0.00153)\end{array}$ \\
\hline 2011 & $\begin{array}{c}0.00018 \\
(0.00029)\end{array}$ & $\begin{array}{l}-0.00062 \\
(0.00033)\end{array}$ & $\begin{array}{c}-0.00207^{* *} \\
(0.00098)\end{array}$ & $\begin{array}{l}0.00106 * * \\
(0.00051)\end{array}$ & $\begin{array}{c}-0.00493^{* *} \\
(0.00209)\end{array}$ \\
\hline 2012 & $\begin{array}{c}0.00034 \\
(0.00029)\end{array}$ & $\begin{array}{l}-0.00043 \\
(0.00033)\end{array}$ & $\begin{array}{l}-0.00132 \\
(0.00098)\end{array}$ & $\begin{array}{c}0.00142 * * * \\
(0.00052)\end{array}$ & $\begin{array}{c}-0.00301 \\
(0.00211)\end{array}$ \\
\hline 2013 & $\begin{array}{c}-0.00006 \\
(0.00031)\end{array}$ & $\begin{array}{c}-0.00039 \\
(0.00036)\end{array}$ & $\begin{array}{c}-0.00126 \\
(0.00105)\end{array}$ & $\begin{array}{c}0.00093 \\
(0.00055)\end{array}$ & $\begin{array}{c}-0.00429 \\
(0.00221)\end{array}$ \\
\hline February & $\begin{array}{c}-0.00013 \\
(0.00019)\end{array}$ & $\begin{array}{c}-0.00022 \\
(0.00021)\end{array}$ & $\begin{array}{c}-0.00188 * * * \\
(0.00063)\end{array}$ & $\begin{array}{c}0.00021 \\
(0.00033)\end{array}$ & $\begin{array}{c}-0.00186 \\
(0.00127)\end{array}$ \\
\hline March & $\begin{array}{l}-0.00001 \\
(0.00019)\end{array}$ & $\begin{array}{c}0.00003 \\
(0.00022)\end{array}$ & $\begin{array}{c}-0.00019 \\
(0.00064)\end{array}$ & $\begin{array}{c}0.00033 \\
(0.00033)\end{array}$ & $\begin{array}{c}0.00107 \\
(0.00128)\end{array}$ \\
\hline April & $\begin{array}{c}0.00037 \\
(0.00020)\end{array}$ & $\begin{array}{l}-0.00001 \\
(0.00022)\end{array}$ & $\begin{array}{l}-0.00068 \\
(0.00065)\end{array}$ & $\begin{array}{c}0.00012 \\
(0.00033)\end{array}$ & $\begin{array}{l}-0.00054 \\
(0.00123)\end{array}$ \\
\hline May & $\begin{array}{c}-0.00014 \\
(0.00018)\end{array}$ & $\begin{array}{c}0.00003 \\
(0.00022)\end{array}$ & $\begin{array}{c}-0.00044 \\
(0.00065)\end{array}$ & $\begin{array}{c}0.00053 \\
(0.00033)\end{array}$ & $\begin{array}{c}0.00016 \\
(0.00125)\end{array}$ \\
\hline June & $\begin{array}{l}-0.00005 \\
(0.00019)\end{array}$ & $\begin{array}{l}-0.00011 \\
(0.00022)\end{array}$ & $\begin{array}{c}0.00055 \\
(0.00065)\end{array}$ & $\begin{array}{c}0.00091 * * * \\
(0.00034)\end{array}$ & $\begin{array}{c}0.00233 \\
(0.00127)\end{array}$ \\
\hline July & $\begin{array}{c}0.00026 \\
(0.00019)\end{array}$ & $\begin{array}{c}0.00026 \\
(0.00023)\end{array}$ & $\begin{array}{c}0.00011 \\
(0.00065)\end{array}$ & $\begin{array}{c}0.00083 * * \\
(0.00033)\end{array}$ & $\begin{array}{c}0.00193 \\
(0.00126)\end{array}$ \\
\hline August & $\begin{array}{c}0.00081^{* * *} \\
(0.00020)\end{array}$ & $\begin{array}{c}0.00001 \\
(0.00022)\end{array}$ & $\begin{array}{c}0.00092 \\
(0.00066)\end{array}$ & $\begin{array}{c}0.00107 * * * \\
(0.00034)\end{array}$ & $\begin{array}{c}0.00349 * * * \\
(0.00129)\end{array}$ \\
\hline September & $\begin{array}{c}0.00128 * * * \\
(0.00022)\end{array}$ & $\begin{array}{c}0.00005 \\
(0.00022)\end{array}$ & $\begin{array}{c}0.00126 \\
(0.00066)\end{array}$ & $\begin{array}{c}0.00097 * * * \\
(0.00034)\end{array}$ & $\begin{array}{c}0.00477 * * * \\
(0.00133)\end{array}$ \\
\hline October & $\begin{array}{c}-0.00026 \\
(0.00019)\end{array}$ & $\begin{array}{c}-0.00059 * * * \\
(0.00022)\end{array}$ & $\begin{array}{c}-0.00403^{* * *} \\
(0.00064)\end{array}$ & $\begin{array}{c}-0.00103 * * * \\
(0.00032)\end{array}$ & $\begin{array}{c}-0.00783 * * * \\
(0.00125)\end{array}$ \\
\hline November & $\begin{array}{c}0.00000 \\
(0.00020)\end{array}$ & $\begin{array}{l}-0.00022 \\
(0.00023)\end{array}$ & $\begin{array}{c}-0.00202^{* * *} \\
(0.00066)\end{array}$ & $\begin{array}{c}0.00006 \\
(0.00034)\end{array}$ & $\begin{array}{c}-0.00268 * * \\
(0.00128)\end{array}$ \\
\hline December & $\begin{array}{c}0.00011 \\
(0.00020)\end{array}$ & $\begin{array}{c}-0.00060 * * * \\
(0.00022)\end{array}$ & $\begin{array}{c}-0.00174 * * * \\
(0.00067)\end{array}$ & $\begin{array}{c}0.00199 * * * \\
(0.00037)\end{array}$ & $\begin{array}{c}0.00215 \\
(0.00139)\end{array}$ \\
\hline PGE & $\begin{array}{c}0.00061^{* *} \\
(0.00029)\end{array}$ & $\begin{array}{c}0.00045 \\
(0.00039)\end{array}$ & $\begin{array}{c}0.00397 * * * \\
(0.00126)\end{array}$ & $\begin{array}{l}-0.00112 \\
(0.00073)\end{array}$ & $\begin{array}{c}0.00465 \\
(0.00349)\end{array}$ \\
\hline $\begin{array}{l}\text { Washington } \\
\text { County }\end{array}$ & $\begin{array}{c}0.00081^{* * *} \\
(0.00031)\end{array}$ & $\begin{array}{c}0.00117 * * * \\
(0.00041)\end{array}$ & $\begin{array}{c}0.00058 \\
(0.00123)\end{array}$ & $\begin{array}{c}-0.00305 * * * \\
(0.00069)\end{array}$ & $\begin{array}{l}-0.00426 \\
(0.00326)\end{array}$ \\
\hline $\begin{array}{l}\text { Clackamas } \\
\text { County }\end{array}$ & $\begin{array}{c}0.00076 * * * \\
(0.00025)\end{array}$ & $\begin{array}{l}-0.00009 \\
(0.00033)\end{array}$ & $\begin{array}{c}-0.00562 * * * \\
(0.00104)\end{array}$ & $\begin{array}{c}-0.00309 * * * \\
(0.00061)\end{array}$ & $\begin{array}{c}-0.01976 * * * \\
(0.00285)\end{array}$ \\
\hline Constant & $\begin{array}{c}-0.00083^{* *} \\
(0.00041)\end{array}$ & $\begin{array}{c}-0.00096 * * \\
(0.00048)\end{array}$ & $\begin{array}{c}0.00396 * * * \\
(0.00145)\end{array}$ & $\begin{array}{l}-0.00069 \\
(0.00080)\end{array}$ & $\begin{array}{c}0.00945 * * * \\
(0.00344)\end{array}$ \\
\hline
\end{tabular}


Observations

2391780

2391780

2391780

2391780

2391780

Notes: All models estimated with OLS. Robust standard errors reported in parentheses. The study period is October $1^{\text {st }}, 2008$ to September $30^{\text {th }}, 2013$. The unit of observation is a beneficiary/month/year.

†Potentially overused surgeries=Spine surgeries for pain; knee and shoulder arthoscopies; and hip and knee replacements.

$* * * ; * *=$ statistically different from zero at the 1\%; $5 \%$ level. 
Appendix Table E. Effect of VIBD on ACT service OOP payments conditional on service use, any utilization of ACT services, and the number of ACT services: Unbalanced panel of beneficiaries

\begin{tabular}{lccccc}
\hline \hline Outcome: & $\begin{array}{c}\text { Sleep } \\
\text { studies }\end{array}$ & Endoscopy & $\begin{array}{c}\text { Advanced } \\
\text { imaging }\end{array}$ & $\begin{array}{c}\text { Potentially } \\
\text { overused } \\
\text { surgeries } \dagger\end{array}$ & Any ACT \\
\hline $\begin{array}{l}\text { Panel A:OOP } \\
\text { payments }\end{array}$ & & & & & \\
\hline $\begin{array}{l}\text { OEBB proportion, } \\
\text { pre-treatment }\end{array}$ & 284.7639 & 160.4122 & 195.2439 & 339.4799 & 210.9595 \\
\hline DD & $\begin{array}{c} \\
\text { 120.53745*** } \\
(15.44707)\end{array}$ & $\begin{array}{c}257.88801^{* * *} \\
(13.58119)\end{array}$ & $\begin{array}{c}143.11983^{* * *} \\
(4.26278)\end{array}$ & $\begin{array}{c}563.67289^{* * *} \\
(21.62901)\end{array}$ & $\begin{array}{c}211.09267^{* * *} \\
(5.43956)\end{array}$ \\
\hline Observations & 5666 & 5897 & 55911 & 11451 & 76448 \\
\hline $\begin{array}{l}\text { Panel B: Any } \\
\text { utilization }\end{array}$ & & & & \\
\hline $\begin{array}{l}\text { OEBB proportion, } \\
\text { pre-treatment }\end{array}$ & 0.0014 & 0.0014 & 0.0120 & 0.0025 & 0.0167 \\
\hline DD & $-0.00027^{* * *}$ & -0.00011 & $-0.00055^{* *}$ & $-0.00040^{* * *}$ & $-0.00126^{* * *}$ \\
& $(0.00008)$ & $(0.00008)$ & $(0.00025)$ & $(0.00012)$ & $(0.00029)$ \\
\hline Observations & 4672864 & 4672864 & 4672864 & 4672864 & 4672864 \\
\hline$\varepsilon \dagger \dagger$ & -0.4556 & -0.0489 & -0.0625 & -0.0964 & -0.0754 \\
\hline
\end{tabular}

Notes: All models estimated with OLS (continuous outcome) or an LPM (binary outcome), and control for beneficiary characteristics reported in Table 2, and employer, month, and year fixed effects. Robust standard errors reported in parentheses. The study period is October $1^{\text {st }}, 2008$ to September $30^{\text {th }}, 2013$. The unit of observation is a beneficiary/month/year. See Table 1 for cost-sharing increases. OOP=copayment+coinsurance.

†Potentially overused surgeries=Spine surgeries for pain; knee and shoulder arthoscopies; and hip and knee replacements.

$\dagger \dagger \varepsilon=$ (percent change quantity) $/$ (percent change price $)=\left(\beta_{Q} /\right.$ mean in service use in pre-treatment period at OEBB $) /\left(\beta_{O O P} /\right.$ mean OOP payment in pre-treatment period at OEBB). $\beta_{O O P}$ reported in Panel A. $* * * ; * *=$ statistically different from zero at the $1 \%$; $5 \%$ level. 
Appendix Table F. Effect of VIBD on ACT service OOP payments conditional on service use including plan fixed effects as covariates

\begin{tabular}{|c|c|c|c|c|c|}
\hline Outcome: & $\begin{array}{c}\text { Sleep } \\
\text { studies }\end{array}$ & Endoscopy & $\begin{array}{c}\text { Advanced } \\
\text { imaging }\end{array}$ & $\begin{array}{c}\text { Potentially } \\
\text { overused } \\
\text { surgeries } \dagger\end{array}$ & Any ACT \\
\hline \multicolumn{6}{|l|}{$\begin{array}{l}\text { Panel A:OOP } \\
\text { payments }\end{array}$} \\
\hline $\begin{array}{l}\text { OEBB proportion, } \\
\text { pre-treatment }\end{array}$ & 284.7639 & 160.4122 & 195.2439 & 339.4799 & 210.9595 \\
\hline $\mathrm{DD}$ & $\begin{array}{c}127.70412^{* * * *} \\
(20.33611)\end{array}$ & $\begin{array}{c}244.05400 * * * \\
(18.39418)\end{array}$ & $\begin{array}{c}134.19976 * * * \\
(5.89089)\end{array}$ & $\begin{array}{c}519.93184 * * * \\
(29.16953)\end{array}$ & $\begin{array}{c}203.45926^{* * *} \\
(7.51284)\end{array}$ \\
\hline Observations & 3172 & 3127 & 29126 & 6337 & 40440 \\
\hline \multicolumn{6}{|l|}{$\begin{array}{l}\text { Panel B: Any } \\
\text { utilization }\end{array}$} \\
\hline $\begin{array}{l}\text { OEBB proportion, } \\
\text { pre-treatment }\end{array}$ & 0.0014 & 0.0014 & 0.0120 & 0.0025 & 0.0167 \\
\hline $\mathrm{DD}$ & $\begin{array}{l}-0.00027 * * \\
(0.00012)\end{array}$ & $\begin{array}{l}-0.00006 \\
(0.00011)\end{array}$ & $\begin{array}{l}-0.00014 \\
(0.00035)\end{array}$ & $\begin{array}{c}-0.00044 * * * \\
(0.00017)\end{array}$ & $\begin{array}{l}-0.00096 * * \\
(0.00041)\end{array}$ \\
\hline Observations & 2391780 & 2391780 & 2391780 & 2391780 & 2391780 \\
\hline$\varepsilon \dagger \dagger$ & -0.4300 & -0.0282 & -0.0170 & -0.1149 & -0.0596 \\
\hline
\end{tabular}

Notes: All models estimated with OLS (continuous outcome) or an LPM (binary outcome), and control for beneficiary characteristics reported in Table 2, and employer, month, and year fixed effects. Robust standard errors reported in parentheses. The study period is October $1^{\text {st }}, 2008$ to September $30^{\text {th }}$, 2013. The unit of observation is a beneficiary/month/year. See Table 1 for cost-sharing increases. OOP=copayment+coinsurance.

†Potentially overused surgeries=Spine surgeries for pain; knee and shoulder arthoscopies; and hip and knee replacements.

$\dagger \dagger \varepsilon=$ (percent change quantity) $/($ percent change price $)=\left(\beta_{Q} /\right.$ mean in service use in pre-treatment period at OEBB $) /\left(\beta_{O O P} /\right.$ mean OOP payment in pre-treatment period at OEBB). $\beta_{O O P}$ reported in Panel A.

$* * * ; * *=$ statistically different from zero at the $1 \%$; $5 \%$ level 
Appendix Table G. Effect of VIBD on ACT service OOP payments conditional on service use including only ACT services that are always listed as an ACT service

\begin{tabular}{|c|c|c|c|c|c|}
\hline Outcome: & $\begin{array}{c}\text { Sleep } \\
\text { studies }\end{array}$ & Endoscopy & $\begin{array}{l}\text { Advanced } \\
\text { imaging }\end{array}$ & $\begin{array}{c}\text { Potentially } \\
\text { overused } \\
\text { surgeries } \dagger\end{array}$ & Any ACT \\
\hline \multicolumn{6}{|l|}{$\begin{array}{l}\text { Panel A:OOP } \\
\text { payments }\end{array}$} \\
\hline $\begin{array}{l}\text { OEBB proportion, } \\
\text { pre-treatment }\end{array}$ & 383.5885 & 289.1243 & 303.8359 & 911.5765 & 378.8394 \\
\hline DD & $\begin{array}{c}111.66988^{* * * *} \\
(24.65274)\end{array}$ & $\begin{array}{c}265.59549 * * * \\
(20.06006)\end{array}$ & $\begin{array}{c}142.56743^{* * *} \\
(8.03078)\end{array}$ & $\begin{array}{c}511.32130 * * * \\
(40.33713)\end{array}$ & $\begin{array}{c}199.92128 * * * \\
(10.48086)\end{array}$ \\
\hline Observations & 2634 & 2612 & 21958 & 3812 & 30316 \\
\hline \multicolumn{6}{|l|}{$\begin{array}{l}\text { Panel B: Any } \\
\text { utilization }\end{array}$} \\
\hline $\begin{array}{l}\text { OEBB proportion, } \\
\text { pre-treatment }\end{array}$ & 0.0013 & 0.0013 & 0.0115 & 0.0019 & 0.0156 \\
\hline DD & $\begin{array}{c}-0.00033^{* * *} \\
(0.00012)\end{array}$ & $\begin{array}{l}-0.00017 \\
(0.00011)\end{array}$ & $\begin{array}{c}-0.00088^{* * *} \\
(0.00033)\end{array}$ & $\begin{array}{l}-0.00023 \\
(0.00014)\end{array}$ & $\begin{array}{c}-0.00163 * * * \\
(0.00039)\end{array}$ \\
\hline Observations & 2391780 & 2391780 & 2391780 & 2391780 & 2391780 \\
\hline$\varepsilon \dagger \dagger$ & -0.8720 & -0.1424 & -0.1631 & -0.2158 & -0.1980 \\
\hline
\end{tabular}

Notes: All models estimated with OLS (continuous outcome) or an LPM (binary outcome), and control for beneficiary characteristics reported in Table 2, and employer, month, and year fixed effects. Robust standard errors reported in parentheses. The study period is October $1^{\text {st }}, 2008$ to September $30^{\text {th }}, 2013$. The unit of observation is a beneficiary/month/year. See Table 1 for cost-sharing increases. OOP=copayment+coinsurance.

†Potentially overused surgeries=Spine surgeries for pain; knee and shoulder arthoscopies; and hip and knee replacements.

$\dagger \dagger \varepsilon=$ (percent change quantity) $/($ percent change price $)=\left(\beta_{Q} /\right.$ mean in service use in pre-treatment period at OEBB $) /\left(\beta_{O O P} /\right.$ mean OOP payment in pre-treatment period at OEBB). $\beta_{O O P}$ reported in Panel A. $* * * ; * *=$ statistically different from zero at the $1 \%$; $5 \%$ level. 
Appendix Table H. Effect of VIBD on use of any ACT service: Separate analysis by Moda Health plans with different levels of changes in general cost-sharing

\begin{tabular}{|c|c|c|}
\hline Outcome: & $\begin{array}{c}\text { High general } \\
\text { cost-sharing changes } \\
\text { (ODS Plans 3-5) }\end{array}$ & $\begin{array}{c}\text { Low general } \\
\text { cost-sharing changes } \\
\text { (ODS Plans 6-8) }\end{array}$ \\
\hline \multicolumn{3}{|l|}{ Panel A:OOP payments } \\
\hline OEBB proportion, pre-treatment & 174.6535 & 262.0892 \\
\hline$T_{1}=T_{1}$ & $\begin{array}{c}234.88531^{* * *} \\
(9.00525)\end{array}$ & $\begin{array}{c}173.28725^{* * *} \\
(9.08917)\end{array}$ \\
\hline Observations & 16316 & 18871 \\
\hline \multicolumn{3}{|l|}{ Panel B: Any utilization } \\
\hline OEBB proportion, pre-treatment & 0.0185 & 0.0147 \\
\hline $\mathrm{DD}$ & $\begin{array}{c}-0.00236^{* * *} \\
(0.00062)\end{array}$ & $\begin{array}{c}-0.00147^{* * *} \\
(0.00051)\end{array}$ \\
\hline Observations & 854640 & 1161957 \\
\hline$\varepsilon \dagger$ & -0.0946 & -0.1510 \\
\hline \multicolumn{3}{|c|}{$\begin{array}{l}\text { Notes: All models estimated with OLS (continuous outcome) or an LPM (binary outcome), and control } \mathrm{f} \\
\text { beneficiary characteristics reported in Table } 2 \text {, and employer, month, and year fixed effects. Robust stan } \\
\text { reported in parentheses. The study period is October } 1^{\text {st }}, 2008 \text { to September } 30^{\text {th }}, 2013 \text {. The unit of obse } \\
\text { beneficiary/month/year. See Table } 1 \text { for cost-sharing increases. OOP }=\text { copayment }+ \text { coinsurance. } \\
\dagger \varepsilon=(\text { percent change quantity }) /(\text { percent change price })=\left(\beta_{Q} / \text { mean in service use in pre-treatment period at }\right. \\
\text { OEBB } /\left(\beta_{O o P} / \text { mean OOP payment in pre-treatment period at OEBB). } \beta_{O o P} \text { reported in Panel A. }\right. \\
* * * ; * *=\text { statistically different from zero at the } 1 \% ; 5 \% \text { level. }\end{array}$} \\
\hline
\end{tabular}


Figure 1. Unadjusted trends in any ACT OOP payments conditional on service use

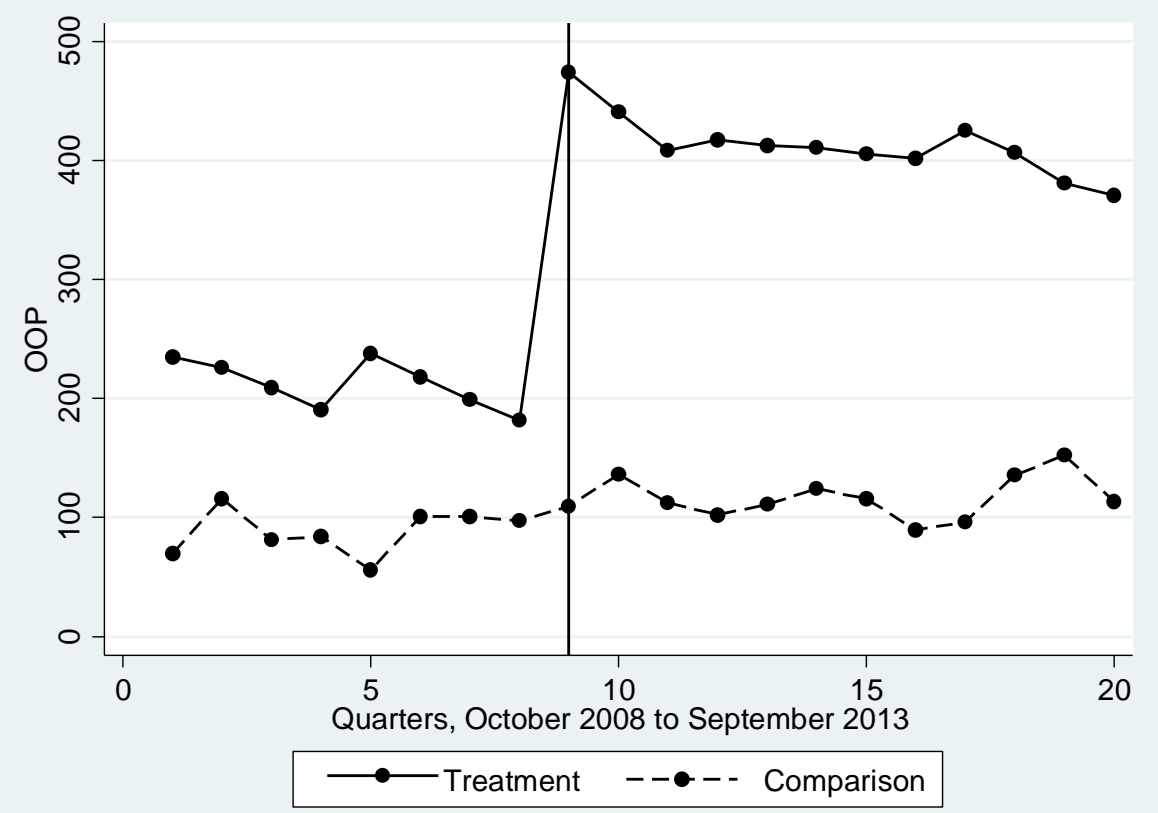

Notes: Data aggregated to the treatment/quarter level. The study period is October $1^{\text {st }}$, 2008 to September $31^{\text {st }} 2013$. Vertical line indicates V-BID effective date at OEBB (October $1^{\text {st }}$, 2010).

Figure 2. Unadjusted trends in any ACT utilization

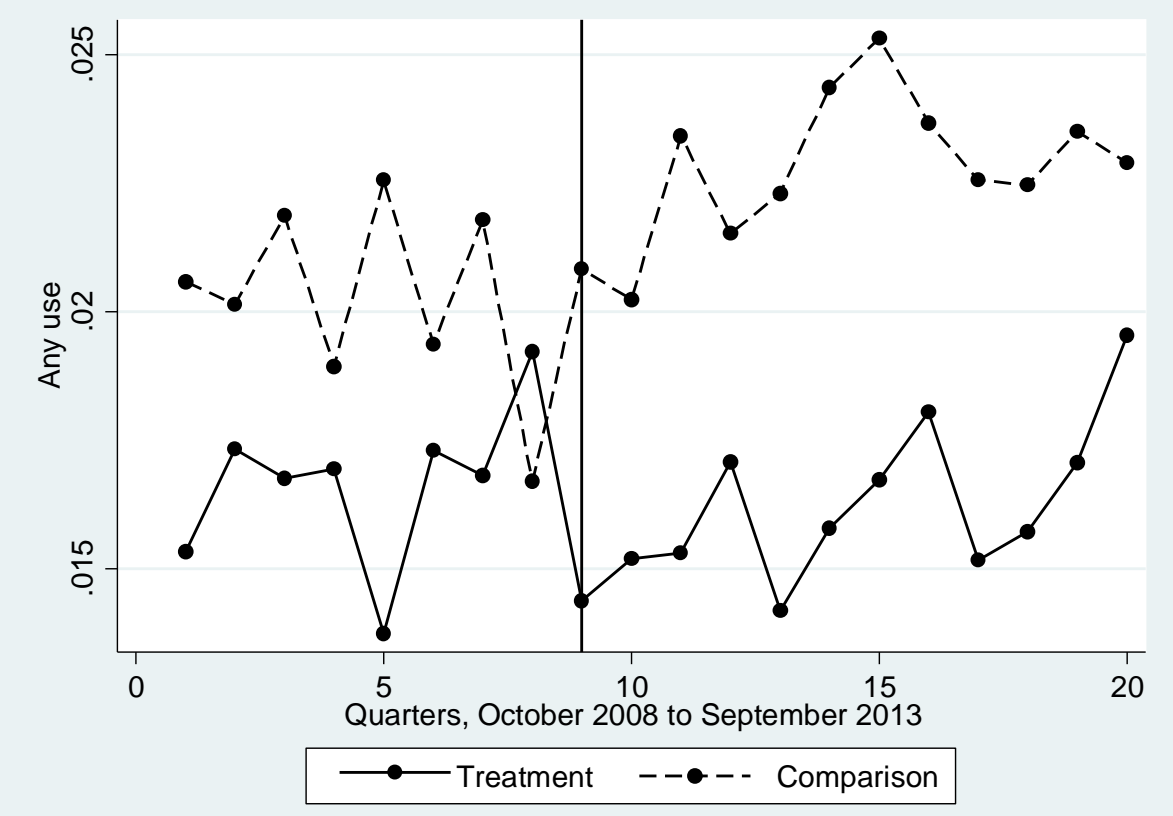

Notes: Data aggregated to the treatment/quarter level. The study period is October $1^{\text {st }}$, 2008 to September $31^{\text {st }} 2013$. Vertical line indicates V-BID effective date at OEBB (October $1^{\text {st }}$, 2010). 
Figure 3. Unadjusted trends in the number of ACT services

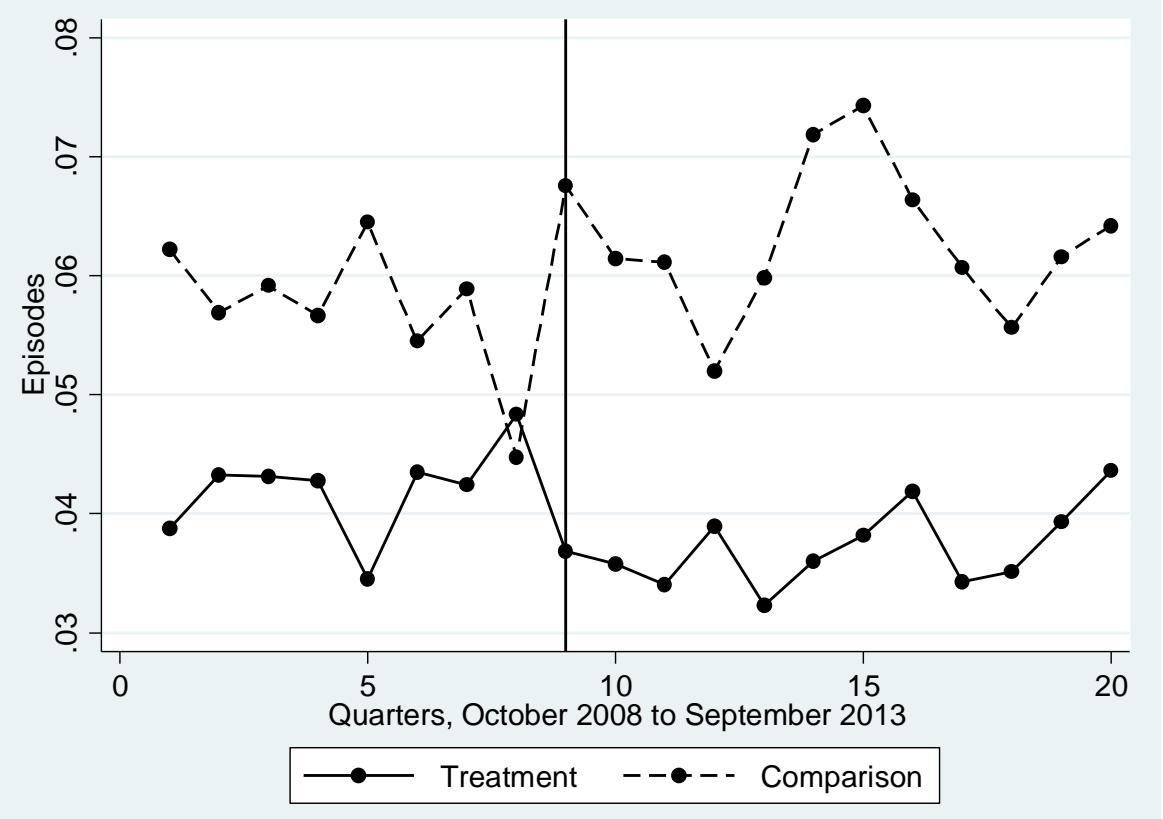

Notes: Data aggregated to the treatment/quarter level. The study period is October $1^{\text {st }}$, 2008 to September $31^{\text {st }} 2013$. Vertical line indicates V-BID effective date at OEBB (October $1^{\text {st }}$, 2010). 


\section{References}

Ai, C. and E. C. Norton (2003). "Interaction terms in logit and probit models." Economics letters 80(1): 123-129.

Baicker, K. and D. Goldman (2011). "Patient cost-sharing and healthcare spending growth." The Journal of Economic Perspectives: 47-68.

Baicker, K. and H. Levy (2015). "Cost sharing as a tool to drive higher-value care." JAMA Internal Medicine 175(3): 399-400.

Beeuwkes, B. M., A. M. Haviland, R. McDevitt and N. Sood (2011). "Healthcare spending and preventive care in high-deductible and consumer-directed health plans." The American journal of managed care 17(3): 222-230.

Brot-Goldberg, Z. C., A. Chandra, B. R. Handel and J. T. Kolstad (2015). What Does a Deductible Do? The Impact of Cost-Sharing on Health Care Prices, Quantities, and Spending Dynamics, National Bureau of Economic Research.

Cameron, A. C. and D. L. Miller (2015). "A Practitioner's Guide to Cluster-Robust Inference." Journal of Human Resources 50(2): 317-372.

Campbell, J. D., F. Allen-Ramey, S. G. Sajjan, E. M. Maiese and S. D. Sullivan (2011).

"Increasing pharmaceutical copayments: impact on asthma medication utilization and outcomes." Am J Manag Care 17(10): 703-710.

Choudhry, N. K., J. Avorn, R. J. Glynn, E. M. Antman, S. Schneeweiss, M. Toscano, L. Reisman, J. Fernandes, C. Spettell and J. L. Lee (2011). "Full coverage for preventive medications after myocardial infarction." New England Journal of Medicine 365(22): 20882097.

Choudhry, N. K., M. A. Fischer, J. L. Avorn, J. L. Lee, S. Schneeweiss, D. H. Solomon, C. Berman, S. Jan, J. Lii, J. J. Mahoney and W. H. Shrank (2012). "The impact of reducing cardiovascular medication copayments on health spending and resource utilization." J Am Coll Cardiol 60(18): 1817-1824.

Farley, J. F., D. Wansink, J. H. Lindquist, J. C. Parker and M. L. Maciejewski (2012). "Medication adherence changes following value-based insurance design." The American journal of managed care 18(5): 265-274.

Fendrick, A. M., D. G. Smith, M. E. Chernew and S. N. Shah (2001). "A benefit-based copay for prescription drugs: patient contribution based on total benefits, not drug acquisition cost." Am J Manag Care 7(9): 861-867.

Garner, S., M. Docherty, J. Somner, T. Sharma, M. Choudhury, M. Clarke and P. Littlejohns (2013). "Reducing ineffective practice: challenges in identifying low-value health care using Cochrane systematic reviews." Journal of Health Services Research \& Policy 18(1): 6-12.

Gawande, A. A., C. H. Colla, S. D. Halpern and B. E. Landon (2014). "Avoiding Low-Value Care." New England Journal of Medicine 370(14): e21.

Gibson, T. B., R. J. Maclean, M. E. Chernew, A. M. Fendrick and C. Baigel (2015). "Valuebased insurance design: benefits beyond cost and utilization." Am J Manag Care 21(1): 32-35. Haviland, A. M., M. D. Eisenberg, A. Mehrotra, P. J. Huckfeldt and N. Sood (2016). "Do "Consumer-Directed" health plans bend the cost curve over time?" Journal of Health Economics 46: 33-51.

Heisler, M., H. Choi, A. B. Rosen, S. Vijan, M. Kabeto, K. M. Langa and J. D. Piette (2010). "Hospitalizations and Deaths Among Adults With Cardiovascular Disease Who Underuse Medications Because of Cost A Longitudinal Analysis." Medical Care 48(2): 87-94. 
Henrikson, N. B., M. L. Anderson, R. A. Hubbard, P. Fishman and D. C. Grossman (2014). "Employee knowledge of value-based insurance design benefits." Am J Prev Med 47(2): 115122.

Hirth, R. A., E. Q. Cliff, T. B. Gibson, M. R. McKellar and A. M. Fendrick (2016). "Connecticut's Value-Based Insurance Plan Increased The Use Of Targeted Services And Medication Adherence." Health Affairs 35(4): 637-646.

Hsu, J., M. Price, R. Brand, G. T. Ray, B. Fireman, J. P. Newhouse and J. V. Selby (2006a).

"Cost-Sharing for Emergency Care and Unfavorable Clinical Events: Findings from the Safety and Financial Ramifications of ED Copayments Study." Health Services Research 41(5): 18011820.

Hsu, J., M. Price, J. Huang, R. Brand, V. Fung, R. Hui, B. Fireman, J. P. Newhouse and J. V. Selby (2006b). "Unintended consequences of caps on Medicare drug benefits." N Engl J Med 354(22): 2349-2359.

Huckfeldt, P. J., A. Haviland, A. Mehrotra, Z. Wagner and N. Sood (2015). Patient Responses to Incentives in Consumer-directed Health Plans: Evidence from Pharmaceuticals, National Bureau of Economic Research.

Kapowich, J. M. (2010). "Oregon's test of value-based insurance design in coverage for state workers." Health Affairs 29(11): 2028-2032.

Lee, J. L., M. L. Maciejewski, S. S. Raju, W. H. Shrank and N. K. Choudhry (2013). "Valuebased insurance design: quality improvement but no cost savings." Health Affairs 32(7): 12511257.

Look, K. A. (2015). "Value-based insurance design and medication adherence: opportunities and challenges." Am J Manag Care 21(1): e78-90.

Maciejewski, M. L., J. F. Farley, J. Parker and D. Wansink (2010). "Copayment reductions generate greater medication adherence in targeted patients." Health Affairs 29(11): 2002-2008. Maciejewski, M. L., D. Wansink, J. H. Lindquist, J. C. Parker and J. F. Farley (2014). "ValueBased Insurance Design Program In North Carolina Increased Medication Adherence But Was Not Cost Neutral." Health Affairs 33(2): 300-308.

Nair, K. V., K. Miller, J. Park, R. R. Allen, J. J. Saseen and V. Biddle (2010). "Prescription copay reduction program for diabetic employees." Popul Health Manag 13(5): 235-245.

National Center for Health Statistics (2016). Health, United States, 2015 with a special feature on racial and ethnic health disparities. Hyattsville, MD.

Norton, E. C., H. Wang and C. Ai (2004). "Computing interaction effects and standard errors in logit and probit models." Stata Journal 4: 154-167.

Organization for Economic Co-operation and Development (2014). OECD Health Statistics 2014 How does the United States compare? OECD Health Statistics. O. f. E. C.-o. a. Development, Organization for Economic Co-operation and Development.

Rosenbaum, L. (2013). "The Whole Ball Game - Overcoming the Blind Spots in Health Care Reform." New England Journal of Medicine 368(10): 959-962.

Sepúlveda, M.-J., M. C. Roebuck, P. Fronstin, P. Vidales-Calderon, A. Parikh and K. Rhee (2016). "Elimination of the Out-of-Pocket Charge for Children's Primary Care Visits: An Application of Value-Based Insurance Design." The Journal of Pediatrics 175: 195-200. Siddiqui, M., E. T. Roberts and C. E. Pollack (2015). "The effect of emergency department copayments for Medicaid beneficiaries following the Deficit Reduction Act of 2005." JAMA Intern Med 175(3): 393-398. 
Smith, M., R. Saunders, L. Stuckhardt and J. M. McGinnis (2013). Best Care at Lower Cost: The Path to Continuously Learning Health Care in America, National Academies Press.

Volpp, K. G., G. Loewenstein and D. A. Asch (2012). "Choosing wisely: low-value services, utilization, and patient cost sharing." JAMA 308(16): 1635-1636.

Wolfers, J. (2006). "Did unilateral divorce laws raise divorce rates? A reconciliation and new results." American Economic Review 96(5): 1802-1820. 